\title{
Potentiometric and Relaxometric Properties of a Gadolinium- based MRI Contrast Agent for Sensing Tissue pH
}

\author{
Ferenc K. Kálmán,$\pm \ddagger$, Mark Woods ${ }^{\dagger, \pm}$, Peter Caravan $\%$, Paul Jurek ${ }^{\dagger}$, Marga Spiller§, Gyula \\ Tircsó $^{ \pm}$, Róbert Király $\ddagger$, Ernő Brücher $¥$, and A. Dean Sherry,$\pm \infty^{\star}$ \\ \pm Department of Chemistry, University of Texas at Dallas, P.O. Box 803066, Richardson, Texas 75083, \\ UNITED STATES. Phone: + 1972883 2907, Fax: + 1972883 2925, E-mail: sherry@utdallas.edu \\ \$Department of Inorganic and Analytical Chemistry, University of Debrecen, P.O. Box 21, Egyetem tér 1, \\ Debrecen, HUNGARY, H-4010. \\ $\uparrow$ Macrocyclics, 2110 Research Row, Suite 425, Dallas, Texas 75235, UNITED STATES. \\ \%EPIX Pharmaceuticals, Inc., 71 Rogers Street, Cambridge, Massachusetts 02142, UNITED STATES. \\ §Department of Radiology, New York Medical College, Valhalla, New York 10595, UNITED STATES \\ $\infty$ Advanced Imaging Research Center, Department of Radiology, University of Texas Southwestern Medical \\ Center, Harry Hines Boulevard, Dallas, Texas 75235, UNITED STATES.
}

\begin{abstract}
The $\mathrm{pH}$ sensitive contrast agent, GdDOTA-4AmP (Gd1) has been successfully used to map tissue $\mathrm{pH}$ by MRI. Further studies now demonstrate that two distinct chemical forms of the complex can be prepared depending upon the $\mathrm{pH}$ at which $\mathrm{Gd}^{3+}$ is mixed with ligand $\mathbf{1}$. The desired $\mathrm{pH}$ sensitive form of this complex, referred to here as a Type II complex, is obtained as the exclusive product only when the complexation reaction is performed above $\mathrm{pH} 8$. At lower $\mathrm{pH}$ values, a second complex is formed that, by analogy with an intermediate formed during preparation of GdDOTA, we tentatively assign this to a Type I complex where the $\mathrm{Gd}^{3+}$ is coordinated only by the appended side-chain arms of $\mathbf{1}$. The proportion of Type I complex formed is largely determined by the $\mathrm{pH}$ of the complexation reaction. The magnitude of $\mathrm{pH}$ dependent change in relaxivity of $\mathrm{Gd} \mathbf{1}$ was found to be less than earlier reported (S. Zhang, K. Wu, and A. D. Sherry, Angew. Chem., Int. Ed., 1999, 38, 3192), likely due to contamination of the earlier sample by an unknown amount of Type I complex. Examination of the NMRD and relaxivity temperature profiles, coupled with information from potentiometric titrations, shows that the amphoteric character of the phosphonate side-chains enables rapid prototropic exchange between the single bound water of the complex with those of the bulk water thereby giving $\mathrm{Gd} \mathbf{1}$ a unique $\mathrm{pH}$ dependent relaxivity that is quite useful for $\mathrm{pH}$ mapping of tissues by MRI.
\end{abstract}

\section{Keywords}

Lanthanides; MRI contrast agents; $\mathrm{pH}$ responsive; Stability constants

E-mail: dean.sherry@utsouthwestern.edu. 


\section{Introduction}

The measurement of $\mathrm{pH}$ in vivo is an important goal in the diagnosis and aetiology of kidney disease and cancer. ${ }^{1-4}$ Although tissue $\mathrm{pH}$ can be measured using microelectrodes, ${ }^{2,} 3$ electrodes are invasive and can only provide a very low resolution distribution of tissue $\mathrm{pH}$. Various NMR spectroscopic approaches have also been used in vivo but they generally suffer from low sensitivity and spatial resolution. Magnetic resonance imaging (MRI) on the other hand provides exquisite anatomical resolution because the MRI signal is largely derived from abundant tissue water so this might be the technique of choice for mapping tissue $\mathrm{pH}$ from organs deep with the body. Although MRI contrast agents have been used for over two decades, 5,6 none of the clinically approved agents are sensitive to tissue $\mathrm{pH}$. To be useful as a $\mathrm{pH}$ reporter, a contrast agent must meet several criteria. The complex must be thermodynamically stable and kinetically inert so that $\mathrm{Gd}^{3+}$ is not released in vivo, 5 the complex itself must be non-toxic, the relaxivity of the complex should respond to changes in $\mathrm{pH}$ over the extremes of tissue $\mathrm{pH}(\sim \mathrm{pH} 5-8)^{2,3}$ and, ideally, the relaxivity of the complex should not be sensitive to endogenous metal ions, anions or proteins. ${ }^{7}$ A number of agents that exhibit changes in relaxivity with $\mathrm{pH}$ have been reported ${ }^{8-12}$ and among them is $\mathrm{Gd} \mathbf{1}$ (GdDOTA-4AmP), an agent that displays a $\mathrm{pH}$ sensitive relaxivity profile that is nearly ideal for in vivo applications. 13 Indeed, pH maps of mouse kidney and implanted tumors have been recorded by MRI using this agent. ${ }^{14-16}$ In this paper, we report studies that examined the relaxation and complexation properties of $\mathrm{Gd} \mathbf{1}$ (Chart 1) in more detail.

\section{Results and Discussion}

\section{Synthesis}

The ligand 1 was synthesized by the route described in Scheme 1. Diethyl phosphite and bromomethyl phthalimide were mixed and heated without solvent. ${ }^{17}$ The ethyl bromide that evolved during the reaction was removed by distillation to afford $\mathbf{3}$ in $99 \%$ yield. The phthalimide group was then removed with hydrazine in ethanol. ${ }^{17,18}$ After column chromatography over silica gel, the amine $\mathbf{4}$ was reacted with bromoacetyl bromide to afford the bromoacetamide $\mathbf{5}$. Alkylation of cyclen with the bromoacetamide $\mathbf{5}$ afforded the protected ligand $\mathbf{6}$ in $61 \%$ yield. The ethyl esters were removed using $30 \% \mathrm{HBr}$ in acetic acid to liberate 1 in $30 \%$ overall yield.

As a general rule, lanthanide complexes of simple DOTA-tetraamide ligands like DOTAM (Chart 1) are readily prepared in acetonitrile by mixing the unprotonated form of the ligand with a lanthanide triflate salt or in water by mixing the ligand with either a lanthanide triflate or lanthanide chloride salt. ${ }^{12,19,20}$ In aqueous media, the $\mathrm{pH}$ of the complexation reaction is an important consideration; lanthanides form insoluble hydroxides above $\mathrm{pH} \sim 6^{21}$ while reactions run at lower $\mathrm{pH}$ values can be quite slow. As a consequence, complexation reactions in water are usually carried out under mildly acidic conditions, typically between $\mathrm{pH} 5-6 .{ }^{12}$,

${ }^{20}$ Since the ligand $\mathbf{1}$ is isolated as a hydrobromide salt using the method described in Scheme 1 , the complexation reaction must be performed in water for solubility reasons. However, in this case, upon mixing a lanthanide salt with the ligand under acidic conditions, i.e. normal complexation conditions, the expected, symmetric, complex structure is not the predominant reaction product. If the reaction $\mathrm{pH}$ is low enough then a single structure of lower symmetry is formed exclusively. This is best illustrated by the ${ }^{1} \mathrm{H}$ NMR spectrum of the ytterbium complex prepared at $\mathrm{pH} 1$ (Figure 1a).

When the reaction is performed at higher $\mathrm{pH}$ values, an increasing amount of the desired, symmetric product is formed. Furthermore, in contrast to most complexation reactions involving lanthanides with DOTA-type ligand systems, raising the $\mathrm{pH}$ above $\sim 6$ does not result in the precipitation of the lanthanide. ${ }^{21} \mathrm{In}$ fact, in this system, the $\mathrm{pH}$ can be raised above 10 
without observable precipitation. This was an important observation because it is not until the $\mathrm{pH}$ of the reaction mixture exceeds 8 that the desired highly symmetrical complex is obtained as the exclusive product. This is seen in the ${ }^{1} \mathrm{H}$ NMR spectrum of the ytterbium complex formed at pH 9 (Figure 1b). Similar results were obtained for other lanthanide complexes.

The difference between the NMR spectrum of the desired product and that of the complex formed under acidic conditions is marked. The desired product shows eight resonances of equal intensity, consistent with the expected $\mathrm{C}_{4}$-symmetry of the complex. Furthermore, the characteristic lanthanide induced shift (LIS) pattern of the DOTA-type framework 22,23 is evident. In contrast, sixteen hyperfine shifted, relatively sharp resonances of equal intensity are evident in the ${ }^{1} \mathrm{H}$ NMR spectrum of the structure formed at low $\mathrm{pH}$, consistent with formation of a different, yet well-defined, complex with $\mathrm{C}_{2}$-symmetry. Although further studies will be required to determine the detail of this structure, it is postulated that this species has a structure similar to that of the intermediate formed during the synthesis of LnDOTA ${ }^{-}$ complexes. In this intermediate, often referred to as a Type I complex, the lanthanide ion sits well above the cyclen ring coordinated only to the four appended carboxyl groups and several water molecules. ${ }^{24}$ The assignment of a $\mathrm{Ln} \mathbf{1}$ species formed at low $\mathrm{pH}$ to a Type I complex is supported by the absorption spectra of the cerium complexes prepared at $\mathrm{pH} 1$ and $\mathrm{pH} 9$. The $4 \mathrm{f}^{1} \rightarrow 4 \mathrm{f}^{0} 5 \mathrm{~d}^{1}$ transition of the cerium ion is found to be extremely sensitive to the coordination environment of the cerium ion and has been reported to be a useful probe of the interconversion of Type I and Type II complexes. ${ }^{24,25}$ These spectra (Figure 2) show that the Ce1 complex formed at low $\mathrm{pH}$ has an absorption maximum similar to that of the Type I complex of CeDOTA so one can conclude that the $\mathrm{Ce}^{3+}$ ion is probably coordinated only by oxygen donors above the macrocyclic ring. The macrocyclic ring does not participate in coordination of the metal ion in this structure presumably because of electrostatic repulsion between the trivalent lanthanide ion and the protonated macrocyclic ring nitrogen atoms. Although usually very short-lived in solution, a crystal structure of a Type I complex of LnDOTAM has been obtained by Parker and co-workers in which the coordination shell of the lanthanide ion is completed by 4 water molecules. ${ }^{26}$ In the case of Ln1, it is reasonable to assume that the phosphonate groups of the pendant arms, which have a high affinity for hard metal ions like the lanthanide ions, are also involved in binding the metal ion to form a Type I complex. This results in a stable structure that, once formed, will persist in solution under acidic conditions for months. It is possible to convert the Type I structure to the more desirable, and more thermodynamically stable, Type II complex by raising the $\mathrm{pH}$. These observations highlight the importance of controlling the reaction $\mathrm{pH}$ when synthesizing the lanthanide complexes of $\mathbf{1}$. To achieve the more highly desired $\mathrm{pH}$ sensitive, Type II complex, the reaction should be performed above $\mathrm{pH} 8$ and preferably around $\mathrm{pH} 9$.

\section{pH responsive relaxometry studies}

The $\mathrm{pH}$ dependent relaxivity curve of $\mathrm{Gd} \mathbf{1}$ is illustrated in Figure 3. These data were collected by starting with a $1 \mathrm{mM}$ solution of the Type II complex prepared at $\mathrm{pH} 9$, as described previously, adjusting the $\mathrm{pH}$ of the sample to $\sim 2$ by addition of hydrochloric acid, and, after each $\mathrm{T}_{1}$ measurement, the sample $\mathrm{pH}$ was raised by addition of small quantities of solid lithium hydroxide monohydrate. Lithium hydroxide was chosen for $\mathrm{pH}$ adjustment because the effect of the lithium ion on the complex was so small that it could not be detected by potentiometry (see below). The $\mathrm{pH}$ profile obtained this way retains many of the features of other $\mathrm{pH}$ profiles reported for simple tetraamide complexes. ${ }^{12,20}$ In particular, at low $\mathrm{pH}$ the relaxivity is high $\left(8.5 \mathrm{mM}^{-1} \mathrm{~s}^{-1}\right)$ but then falls off sharply as the $\mathrm{pH}$ is increased to $\mathrm{pH} 4.5$ after which it begins to increase again (Figure 3). This is where the $\mathrm{pH}$ profile of $\mathrm{Gd} \mathbf{1}$ deviates from those of simpler tetraamide derivatives. Whereas the relaxivity of most other tetraamide derivatives minimizes around $\mathrm{pH} 3$ and remains low up to $\mathrm{pH} \sim 9$, the relaxivity of $\mathrm{Gd} \mathbf{1}$ rises from $4.4 \mathrm{mM}^{-1} \mathrm{~s}^{-1}$ at 
$\mathrm{pH} 4.5$ and reaches a maximum of $5.3 \mathrm{mM}^{-1} \mathrm{~s}^{-1}$ at $\mathrm{pH} 6.3$, then falls off again as the $\mathrm{pH}$ is raised above 6.3 until it reaches a minimum of $3.4 \mathrm{mM}^{-1} \mathrm{~s}^{-1}$ above $\mathrm{pH} 9$.

Although the $\mathrm{pH}$ profile shown in Figure 3 differs in the magnitude of the change in relaxivity from that originally reported for $\mathrm{Gd} \mathbf{1},{ }^{13}$ it does retain the same broad characteristics. The accuracy of this new profile was independently verified by recording nuclear magnetic relaxation dispersion (NMRD) profiles of a different sample of carefully prepared $\mathrm{Gd} \mathbf{1}$ at three temperatures over the $\mathrm{pH}$ range $5-8.5$ (Figure 4). The NMRD profiles recorded at $25^{\circ} \mathrm{C}$ show the same trend and relaxivity values with changing $\mathrm{pH}$ at $20 \mathrm{MHz}$ as the $\mathrm{pH}$ profile reported in Figure 3. Furthermore, a profile corresponding to that previously published ${ }^{13}$ could be obtained by preparing a sample of $\mathrm{Gd} \mathbf{1}$ at a $\mathrm{pH}$ known to be too low to allow complete formation of the Type II complex. When the $\mathrm{pH}$ profile of a sample initially prepared at $\mathrm{pH} 4$ was measured using a identical protocol as that described for Figure 3, the profile closely resembled the one previously reported. ${ }^{13}$ Presumably the Type I complex has a greater contribution to relaxation at the lower end of the $\mathrm{pH}$ scale. As the $\mathrm{pH}$ is increased, the complex is gradually converted into the Type II complex and thus the profiles display similar relaxivities by $\mathrm{pH} 9$. It should be noted that the Type II complex was used to generate the in vivo maps of tissue $\mathrm{pH}$ using this compound as evidenced by the similarity of the $\mathrm{pH}$ dependent relaxivity curves published in those papers ${ }^{14-16}$ with those of Figure 3.

Inspection of the NMRD profiles of Figure 4 provides further insights into this $\mathrm{pH}$ sensitive complex. The profiles display a general shape that is similar to other low molecular weight DOTA-type chelates of $\mathrm{Gd}^{3+}$. In the region of interest for imaging, i.e., above $10 \mathrm{MHz}$, the measured relaxivity can be affected by the hydration number $(q)$, the water exchange rate (1/ $\tau_{\mathrm{M}}$ ) and the rotational correlation time of the complex $\left(\tau_{\mathrm{R}}\right){ }^{27-31}$ For typical low molecular weight chelates, rapid molecular reorientation largely determines the observed relaxivity. As molecular reorientation is slowed, the relaxivity near $20-30 \mathrm{MHz}$ increases and this is typically seen in an NMRD profile as a characteristic high field "hump". 32,33 The absence of this "hump" in any of the NMRD profiles of Gd1 shows that the complex undergoes rapid molecular reorientation at all $\mathrm{pH}$ values. Thus, we may conclude that the $\mathrm{pH}$ responsive behaviour of $\mathrm{Gd} \mathbf{1}$ does not originate with changes in $\tau_{\mathrm{R}}$ arising from $\mathrm{pH}$ dependent aggregation of the complex. ${ }^{33}$ Since $q$ has also been shown to be $\mathrm{pH}$ independent in this complex $(q=1),{ }^{13}$ the origin of the $\mathrm{pH}$ response at high fields must reflect changes in the water (or proton) exchange rate $\left(1 / \tau_{\mathrm{M}}\right)$ or changes in the second hydration sphere with changing $\mathrm{pH} .{ }^{34}$ The relaxivity of this complex also displays a different temperature dependence at each $\mathrm{pH}$ value (discussed further below), a further indication that $\tau_{\mathrm{M}}$ is the factor most influenced by changes in $\mathrm{pH}$ in this complex.

It is important to note that the rate of water molecule exchange as determined by variable temperature ${ }^{17} \mathrm{O}$ NMR experiments on the Dy 1 complex is unaffected by changes in $\mathrm{pH} .{ }^{13}$ However, bulk water relaxation in this system does not require rapid molecular exchange when proton exchange would have the same effect on measured relaxivity values. This is indeed the case for $\mathrm{Gd} \mathbf{1}$. Given that the constitution of $\mathrm{Gd} \mathbf{1}$ is so important to the observed $\mathrm{pH}$ dependent relaxivity behaviour, and perhaps also the stability and safety of the complex, there is a clear need for a reliable assay of the products of the complexation reaction prior to use of this complex as a pH sensor. Since the electronic properties of gadolinium preclude the use of NMR for this purpose, an alternative technique was sought.

\section{Potentiometric Studies}

The protonation constants of the ligand $\mathbf{1}$ were determined by potentiometric titration, eight protonation steps were found in the $\mathrm{pH}$ range $1.7-12.5$ (Table 1). Although the same number of protonation steps was observed in the presence of $\mathrm{Me}_{4} \mathrm{~N}^{+}$and $\mathrm{K}^{+}$, the protonation constants in $\mathrm{KCl}$ were significantly depressed relative to $\mathrm{Me}_{4} \mathrm{NCl}$, especially $K_{1}{ }^{\mathrm{H}}$. This indicates that 
the $\mathrm{K}^{+}$ion is not completely inert with respect to $\mathbf{1}$ and does in fact form a weak complex with the ligand.

When comparing these protonation constants with those of other DOTA-tetraamide derivatives, 25,35 it is clear that the highest constant can be assigned to the first protonation of the cyclen ring. While the two highest protonation constants in systems such as these can typically be traced to macrocyclic nitrogen atoms,, $36-38$ this system is less clear because at least four of the six highest protonation constants must correspond to four $\mathrm{PO}_{3}{ }^{2-} \rightarrow \mathrm{PO}_{3} \mathrm{H}^{-}$ protonation steps, one on each of the four pendant arms. ${ }^{39}$ Thus, while the first six protonation steps can be assigned to two of the macrocylic amines and four phosphonates, the next two protonation steps are more difficult to assign. Only rarely is a third protonation step for the cyclen ring observed in this range 25,35 and yet the $\log K$ values, 2.46 and 1.92, are in the range expected for further protonation of the macrocyclic ring. However, these two protonation constants are also in the range expected for a second phosphonate protonation step, $\mathrm{PO}_{3} \mathrm{H}^{-} \rightarrow$ $\mathrm{PO}_{3} \mathrm{H}_{2}{ }^{39}$ so further studies will be necessary to delineate the exact microscopic sites of these final two protonation steps.

Further titrations of $\mathbf{1}$ were performed in the presence of variable amounts of $\mathrm{Na}^{+}, \mathrm{K}^{+}$or $\mathrm{Ca}^{2+}$ in a constant ionic background of $1.0 \mathrm{M} \mathrm{Me}_{4} \mathrm{NCl}$. The stabilities of complexes formed between these ions and $\mathbf{1}$ are summarized in Table 2. Although $\mathrm{K}^{+}$forms the weakest complex of these three ions, its interaction with $\mathbf{1}$ is still significant. Among these three ions, $\mathrm{Ca}^{2+}$, not surprisingly, forms the most stable complex with $\mathbf{1}$, the magnitude of which is similar to that observed for other DOTA-tetraamide ligands. 25,35 Unless a Type I complex is formed between $\mathrm{Ca}^{2+}$ and $\mathbf{1}$ that is particularly strong, a $\log K_{\mathrm{CaL}}$ value of 11.16 suggests that this reflects a Type II complex where the $\mathrm{Ca}^{2+}$ is bound by the macrocyclic ring as well as the amide oxygen atoms. This is supported by the observation that the $\mathrm{pH}$ was slow to stabilize after each addition of base, consistent with relatively slow formation kinetics of a Type II Ca1 complex since formation of a Type I complex would be expected to be rapid.

Although the coordination chemistry and size of the $\mathrm{Ca}^{2+}$ ion is similar to the lanthanide ions, potentiometric titrations of $\mathbf{1}$ in the presence of $\mathrm{Gd}^{3+}$ showed quite different behaviour from that of $\mathrm{Ca}^{2+}$. In this case, there was an initial rapid release of protons when $\mathrm{Gd}^{3+}$ was added to the ligand $\mathbf{1}$ under acidic conditions, presumably the result of release of phosphonate bound protons during formation of a Type I complex. We have already seen that the greater nuclear charge of the $\mathrm{Gd}^{3+}$ ion results in a strong interaction with the phosphonates under these conditions. Although the results of NMR and spectrophotometric experiments have shown that conversion to a Type II complex does occur as more base is added, this process is slow. Furthermore, as the $\mathrm{Gd}^{3+}$ ion drops into the ligand cage it ceases to bind to the phosphonate groups and these groups are then able to act as buffers to absorb protons released during movement of the $\mathrm{Gd}^{3+}$ ion into the macrocyclic ring. These two effects, in combination, explain why subsequent evolution of protons in the titration of $\mathbf{1}$ with $\mathrm{Gd}^{3+}$ was not observed. Since the release of protons from the macrocycle cannot be measured during this rearrangement, a stability constant for Gd1 cannot be determined by potentiometry alone. However, it is possible to approximate the stability constant for Gd1 by extrapolating from the value found for the $\mathrm{Ca}^{2+}$ system. In general, the $\log K_{\mathrm{GdL}}$ values for $\mathrm{Gd}^{3+}$ complexes in other DOTA-tetraamide systems are a factor of $1.3-1.4$ greater than those measured for the corresponding $\mathrm{Ca}^{2+}$ complexes, ${ }^{25,35}$ so one can estimate with some confidence that the value of $\log K_{\mathrm{GdL}}$ for Gd1 lies between 14.2 and 15.6 based upon the $\log K_{\mathrm{CaL}}$ value measured here for Ca1 (Table 2). Given that $\mathrm{pH}$ changes are detected during formation of $\mathrm{Ca}$, this also lends support to the idea that $\mathrm{Ca}^{2+}$ does not form the same stable Type I complex with $\mathbf{1}$ as do the lanthanide ions.

The protonation constants of a sample of Gd1, prepared at $\mathrm{pH} 9$ such that only the Type II complex was present, were also determined by potentiometric titration. The values of these 
protonation constants (Table 3) are in the same range as those determined by titration of the ligand alone. If the phosphonate groups of the ligand pendant arms are able to participate in metal ion binding, resulting in an unusually stable Type I complex with lanthanide ions, then the question of their involvement in metal binding once the complex with $\mathrm{Gd}^{3+}$ has been formed should also be addressed. Accordingly, potentiometric titrations of the Type II complex of $\mathrm{Gd} \mathbf{1}$ were performed also in the presence of $\mathrm{Ca}^{2+}, \mathrm{Cu}^{2+}$ and $\mathrm{Zn}^{2+}$. Each of these metal ions was found to form a Gd1 $\cdot \mathrm{M}$ complex with $\log K_{\mathrm{GdLM}}$ values ranging from 1.87 to 5.39 (Table 4). Although $\mathrm{Ca}^{2+}$ forms the weakest ternary complex of the three metal ions studied, the potential for interference by calcium is perhaps greatest because it is present in much higher concentrations in vivo than either $\mathrm{Cu}^{2+}$ or $\mathrm{Zn}^{2+}$. Although the total concentration of $\mathrm{Zn}^{2+}$ and $\mathrm{Cu}^{2+}$ in vivo are $\approx 16 \mu \mathrm{M}$ and $\approx 18 \mu \mathrm{M}$, respectively, the concentrations of these ions available for exchange are even lower, $\left[\mathrm{Zn}^{2+}\right] \approx 10 \mu \mathrm{M},\left[\mathrm{Cu}^{2+}\right] \approx 1.0 \mu \mathrm{M} .{ }^{40}$ In contrast the concentration of calcium in vivo can be as high as $2.5 \mathrm{mM}{ }^{40}$ Binding of zinc or copper by $\mathrm{Gd} \mathbf{1}$ is unlikely to have any significant effect on the $\mathrm{pH}$ dependent relaxivity curve but the effect of calcium binding on a typical MRI contrast agent dose of $0.1-0.3 \mathrm{mmol} \mathrm{kg}^{-1}$ could be more severe. There are also significant concentrations of sodium and potassium ions present in vivo, however, in light of the small binding constant found for $\mathrm{Ca}^{2+}$ (Table 4) and given that the binding constants of $\mathrm{Na}^{+}$and $\mathrm{K}^{+}$with the free ligand were so much weaker than that of $\mathrm{Ca}^{2+}$, the formation of GdL·M complexes with these ions were not studied by potentiometry.

\section{The effect of metal ions on relaxivity and the origins of the $\mathrm{pH}$ response}

To assess whether $\mathrm{Ca}^{2+}$ or other endogenous metal ions might have an effect on the relaxivity of $\mathrm{Gd} \mathbf{1}$, the $\mathrm{pH}$ relaxivity profile was recorded in solutions that simulate the levels of these ions in vivo $\left(135 \mathrm{mM} \mathrm{NaCl}, 5 \mathrm{mM} \mathrm{KCl}\right.$ and $2.5 \mathrm{mM} \mathrm{CaCl}_{2}$ ). The relaxivity profile measured in the presence of these ions was similar to that obtained in the absence of these cations (Figure 3 ). The primary difference between the two profiles is a small shift in the relaxivity maxima from $\mathrm{pH} 6.3$ to $\mathrm{pH} 6.0$ in the presence of endogenous metal ions. This is presumably the result of a small reduction in the protonation constants of $\mathrm{Gd} \mathbf{1}$ resulting from the presence of the metal ions (compare the first protonation constants of $\mathrm{Gd} \mathbf{1}(7.20$, Table 3$)$ versus $\mathrm{Gd} \mathbf{1} \cdot \mathrm{Ca}^{2+}$ (6.94, Table 4)). The concomitant shift in the relaxivity maxima and change in phosphonate group protonation constants indicates that the phosphonate groups are indeed responsible for the $\mathrm{pH}$ sensitive relaxivity of this complex. Thus, although it may be important to account for the effect of endogenous metal ions when using $\mathrm{Gd} \mathbf{1}$ to determine $\mathrm{pH}$, the presence of these metal ions does not diminish the utility of $\mathrm{Gd} \mathbf{1}$ as a $\mathrm{pH}$ sensor in vivo.

The involvement of the phosphonate pendant arms in defining the relaxivity of Gd1 is further supported by the potentiometric data. From the protonation constants reported in the previous section, it is possible to generate a speciation diagram of the different protonation states of $\mathrm{Gd} 1$. When this speciation diagram is plotted on the same axis as the $\mathrm{pH}$ dependent relaxivity profile of $\mathrm{Gd} \mathbf{1}$, the significance of protonation of the phosphonate groups becomes immediately apparent (Figure 5). The relaxivity maximum at $\mathrm{pH} 6.3$ is exactly coincidental with the maximum concentration of the diprotonated complex, $\mathrm{GdLH}_{2}{ }^{3-}$, suggesting that it is this species that has the maximal effect on the measured relaxivity. A multiple regression fitting of these data to Eqn. 1 was performed to estimate the relaxivity of each protonated species and thus the contribution of each species to the observed relaxivity. For this analysis, it was assumed that the fully deprotonated species, GdL, the only species present above $\mathrm{pH} 9.5$, represents the outer sphere contribution to the relaxivity at each $\mathrm{pH}$ value. With this assumption, $\mathrm{r}_{1}{ }^{\text {is }}$ could be simplified to Eqn. 2. Statistically significant $(\alpha=0.05)$ relaxivity values for each species were found with a regression coefficient $\left(\left\langle\mathrm{r}_{1}{ }^{\mathrm{os}}>2\right)\right.$ of 0.96 (Table 5). The significance of protonation state of the phosphonates to the relaxivity of each species is immediately apparent. The highest relaxivities are observed for those species that contain a mixture of mono and 
unprotonated phosphonates, and the highest relaxivity is observed when these are balanced, i.e. for $\mathrm{GdLH}_{2}^{3-}$.

$$
\begin{gathered}
r_{1}^{o b s}-r_{1}^{o s}=r_{1}^{H^{+}}\left[H^{+}\right]+r_{1}^{G d L H_{4}^{-}}\left[G d L H_{4}^{-}\right]+r_{1}^{G d L H_{3}^{2-}}\left[G d L H_{3}^{2-}\right]+r_{1}^{G d L H_{2}^{3-}}\left[G d L H_{2}^{3-}\right]+r_{1}^{G d L H^{4-}}\left[G d L H^{4-}\right]+r_{1}^{G d L^{5-}}\left[G d L^{5-}\right] \\
r_{1}^{i s}=r_{1}^{H^{+}}\left[H^{+}\right]+r_{1}^{G d L H_{4}^{-}}\left[G d L H_{4}^{-}\right]+r_{1}^{G d L H_{3}^{2-}}\left[G d L H_{3}^{2-}\right]+r_{1}^{G d L H_{2}^{3-}}\left[G d L H_{2}^{3-}\right]+r_{1}^{G d L H^{4-}}\left[G d L H^{4-}\right]
\end{gathered}
$$

To investigate this further, variable temperature relaxivity $(20 \mathrm{MHz})$ measurements of Gd1 were carried out at $\mathrm{pH} 6.2$ (near the relaxivity peak at $25^{\circ} \mathrm{C}$ ) and at $\mathrm{pH} 8.3$ (near the relaxivity minimum at $25^{\circ} \mathrm{C}$ ). These data are shown in Figure 6, along with previously published data for $\mathrm{Gd} 2 .{ }^{41}$ There are three contributors to relaxivity: the contribution from an exchangeable inner-sphere water $\left(\mathrm{r}_{1}{ }^{\text {is }}\right)$, the contribution from long lived (ps $\left.-\mathrm{ns}\right)$ waters/protons in the second sphere $\left(\mathrm{r}_{1}{ }^{\text {ss }}\right)$, and outer-sphere relaxation determined by the distance of closest approach and the water diffusion rate $\left(\mathrm{r}_{1}{ }^{\mathrm{os}}\right)$. Outer- and second-sphere relaxivity will always increase inversely with temperature; the correlation times for these processes are so short that the fast exchange condition is always met. For gadolinium complexes of the size of Gd1, the $\mathrm{T}_{1}$ of the coordinated water protons $\left(\mathrm{T}_{1 \mathrm{M}}\right)$ is on the order of $1-10 \mu \mathrm{s}$. Lanthanide complexes of DOTAtetraamide complexes have very slow inner-sphere water exchange rates with water residency times on the order of microseconds. ${ }^{12,20,41}$ The relaxivity of the GdDOTA-tetraamide complexes can therefore span the slow to intermediate to fast exchange regime over the liquid water temperature range. The result is that relaxivity first increases with temperature (slow exchange, $\tau_{M}>T_{1 M}$ ) and then decreases (fast exchange, $T_{1 M}>\tau_{M}$ ).

Qualitatively the data in Figure 6 are quite revealing. The sample at $\mathrm{pH} 8.3$ has high relaxivity at low temperature that decreases as temperature is increased until about $310 \mathrm{~K}$ when the relaxivity starts to increase. This is consistent with relaxivity dominated by outer-and secondsphere mechanisms at low temperatures, but with little contribution from the slow exchanging inner-sphere water protons. As temperature increases, these inner-sphere protons exchange more rapidly and contribute significantly to relaxivity. Going higher in temperature, one would expect relaxivity to peak and then decline as the inner-sphere exchangeable protons move out of the slow exchange regime. This behaviour has been observed in other systems, notably $\mathrm{Gd} 2$ (Figure 6). The temperature dependence of the sample at $\mathrm{pH} 6.2$ is quite different in that the relaxivity always decreases with temperature, although this decline is not mono-exponential and there is a plateau of sorts between $300-320 \mathrm{~K}$. One explanation for change in the temperature profile is more rapid exchange of the inner-sphere water protons at $\mathrm{pH} 6.2$, moving the system out of slow exchange at a lower temperature. Another possibility is an increase in the $2^{\text {nd }}$ sphere relaxivity of the complex due to phosphonate protons with long residence lifetimes at this lower $\mathrm{pH}$.

Comparing the relaxivity of $\mathrm{Gd} \mathbf{1}$ at low temperatures with that of $\mathrm{Gd} \mathbf{2}$ it is clear that a significant $2^{\text {nd }}$-sphere effect contributes to the relaxivity of Gd1. A similar second sphere contribution has been observed with other gadolinium-phosphonate complexes in which the phosphonate groups is bound directly to gadolinium. ${ }^{42-44}$ This second-sphere effect complicates any attempts to analyze the data in a quantitative sense and, given the complex speciation of $\mathrm{Gd} \mathbf{1}$ in solution (Figure 5), an unambiguous analysis of the data is impossible. Nevertheless, it was found to be instructive to model the temperature dependence of $\mathrm{Gd} \mathbf{1}$ to two simple models, each looking at a mechanistic extreme. In both models, it was assumed that only one species is present at each $\mathrm{pH}$. Model I took the assumption that the outer- and second-sphere contributions to relaxivity at a given temperature were the same regardless of $\mathrm{pH}$ and that their sum $\left(\mathrm{r}_{1}{ }^{\mathrm{os}}+\mathrm{r}_{1}{ }^{\mathrm{ss}}\right)$ followed an exponential dependence with temperature. It was also assumed that the correlation time for inner-sphere relaxation is the same at both $\mathrm{pH}$ values, i.e. that rotational diffusion and electronic relaxation do not change with $\mathrm{pH}$, and that this correlation time has an exponential dependence with temperature. Model I tests whether 
the differences in $\mathrm{r}_{1}$ versus temperature for the two $\mathrm{pH}$ samples can be explained solely by a change in the exchange rate of the inner-sphere protons. The best fit of Model I to the experimental data obtained for Gd1 is shown in Figure 7a (model details and parameters can be found in supporting information). Also shown are the contributions from second- and outersphere relaxivity and the inner-sphere contributions at both $\mathrm{pH}$ values. From Figure $7 \mathrm{a}$ is can clearly be seen that this simple model explains the data well and supports the hypothesis that relaxivity differences are a result of different inner-sphere proton exchange rates.

Model II takes the other extreme and assumes that the inner-sphere proton exchange rate is the same at both $\mathrm{pH}$ values. In this model, it was assumed that the outer-sphere relaxivity of $\mathrm{Gd} \mathbf{1}$ is the same at both $\mathrm{pH}$ values and is identical to that determined for $\mathrm{Gd} 2$. Model II considers a separate second-sphere component to relaxivity that is different at the two $\mathrm{pH}$ values. Model II tests whether the differences in $\mathrm{r}_{1}$ versus temperature for the $\mathbf{G d} \mathbf{1}$ at two different $\mathrm{pH}$ values can be explained solely by second-sphere effects. The best fit to the data using Model II is shown in Figure $7 \mathrm{~b}$ and clearly does not explain the data well. The only way to reproduce the "bulge" in the $\mathrm{pH} 6.2$ data and the high temperature increase in the $\mathrm{pH} 8.3$ data is with different inner-sphere proton exchange rates.

Since it is certain that Gd1 does have a second-sphere contribution to relaxivity the reality of the situation probably lies somewhere between these two models. However, it appears probable that inner-sphere water proton exchange is significantly faster at $\mathrm{pH} 6.2$ than at $\mathrm{pH} 8.3$. The rate of whole water exchange in Dy 1 was found to be unaffected by changes in $\mathrm{pH},{ }^{13}$ thus it must be the rate of prototropic exchange in $\mathrm{Gd} \mathbf{1}$ that is altered by $\mathrm{pH}$. Presumably $\mathrm{GdLH}_{2}{ }^{3-}$, the predominant species in solution at $\mathrm{pH}$ 6.2, exhibits more rapid prototopic exchange of the coordinated water protons with those of the bulk solvent than do the other protonated states of the complex. The phosphonates in the $\mathrm{GdLH}_{2}{ }^{3-}$ species, two of which are completely deprotonated and two of which are monoprotonated, must be responsible for this rapid prototropic exchange. One can envision a situation in which the two deprotonated phosphonates located trans to one another in the complex are close enough to the coordinated water molecule to act as general bases for deprotonating the $\mathrm{Gd}^{3+}$-bound water molecule. The mono-protonated phosphonates then act as acids, simultaneously contributing protons to the coordinated water molecule as illustrated in Figure 8. The relaxed protons, once transferred from the water molecule to the phosphonate groups, may then be exchanged with protons in the bulk solvent resulting in transfer of the relaxation of the bulk solvent. In this scenario, the presence of two base and two acid equivalents, in a trans orientation, would be expected to be the most efficient configuration for promoting this proton exchange reaction. Thus, it is not surprising that the complex $\mathrm{GdLH}_{2}{ }^{3-}$ exhibits the highest relaxivity of all protonation species. The protonated forms, $\mathrm{GdLH}_{4}{ }^{-}$and $\mathrm{GdLH}_{3}{ }^{2-}$, also exhibit high relaxivities because, while not as well balanced in terms of acidic and basic phosphonates as in $\mathrm{GdLH}_{2}{ }^{3-}$, they are still both able to catalyze prototropic exchange through a mixture of acids and bases. Once the phosphonates are unable to supply either acidic or basic groups, catalysis by prototropic exchange ceases and relaxivity drops off to values similar to that observed for other DOTAtetraamide derivatives.

\section{Conclusions}

$\mathrm{Gd} \mathbf{1}$ changes relaxivity over a $\mathrm{pH}$ range that is near ideal for measuring $\mathrm{pH}$ in vivo. ${ }^{14-16}$ Care must be taken when preparing samples of $\mathrm{Gd} \mathbf{1}$ because the ligand can form distinctly different complexes with $\mathrm{Gd}^{3+}$, the complex formed being strongly influenced by the initial $\mathrm{pH}$ at which the complexation reaction is run. The current study shows that the complexation reaction should be run at a $\mathrm{pH}$ no lower than 9 to produce only the desired $\mathrm{pH}$ sensitive, Type II product needed for imaging $\mathrm{pH}$ by MRI. A Type I complex formed under more acidic conditions has a higher relaxivity at lower $\mathrm{pH}$ values than the Type II complex so even small amounts of this product 
can affect the calibration curve needed for quantifying tissue $\mathrm{pH}$. Other adventitious metal ions present in biological samples do bind with $\mathrm{Gd} \mathbf{1}$ to form $\mathrm{GdL} \cdot \mathrm{M}$ ternary complexes. $\mathrm{Ca}^{2+}$ offers the greatest potential for interference because the relaxivity versus $\mathrm{pH}$ curve is altered somewhat in the presence of this ion, although calibration curves run in the presence of $\mathrm{Ca}^{2+}$ should easily account for these differences. Potentiometric and relaxometric data for Gd1 at different $\mathrm{pH}$ values show that it is the phosphonates of the pendant arms that gives the complex its unique $\mathrm{pH}$ responsive behaviour. When the phosphonate groups of one complex are able to act in concert as acids and bases, catalysis of prototropic exchange results leads to an enhanced relaxivity over a $\mathrm{pH}$ range that is useful for biological $\mathrm{pH}$ imaging.

\section{Experimental Section}

\section{General}

${ }^{1} \mathrm{H}$ NMR spectra were recorded on a JOEL Eclipse 270 spectrometer operating at $270.17 \mathrm{MHz}$, a Varian Mercury 300 spectrometer operating at $299.95 \mathrm{MHz}$ and a Varian Inova 500 spectrometer operating at $499.95 \mathrm{MHz} .{ }^{31} \mathrm{P}$ NMR spectra were recorded on a Varian Mercury 300 spectrometer operating at $121.47 \mathrm{MHz}$. Longitudinal relaxation times were measured using the inversion recovery method on a MRS-6 NMR analyzer from the Institut "Jožef Stefan", Ljubljana, Slovenjia operating at $20 \mathrm{MHz}$. Relaxivity was determined by linear regression analysis of relaxation rates of six solutions $(0.5-10 \mathrm{mM})$. The $\mathrm{pH}$ of samples for relaxivity measurements were adjusted by addition of either lithium hydroxide monohydrate or $p$ toluenesulfonic acid monohydrate in order to avoid dilution.

\section{Synthesis}

Diethyl phthalimidomethylphosphonate (3) $\mathbf{1 7}$ —Triethylphosphite (40.53 g, 243.9 mmol) and $N$-bromomethylphthalimide $(48.8 \mathrm{~g}, 203.3 \mathrm{mmol})$ were heated, neat, to $90{ }^{\circ} \mathrm{C}$ for 3 hours. A distillation apparatus was then fitted and the reaction temperature increased to 105 ${ }^{\circ} \mathrm{C}$ until no more distillate was produced. The reaction was allowed to cool to room temperature and the residue dissolved in diethyl ether $(300 \mathrm{~mL})$. Hexanes $(600 \mathrm{~mL})$ were added and the resulting solution cooled to $-20 \mathrm{C}$ and the product allowed to crystallize. The crystals were recovered by filtration and dried under vacuum to afford the title compound as a colourless solid $(59.7 \mathrm{~g}, 99 \%)$.

$\mathrm{mp}=63.5-64{ }^{\circ} \mathrm{C} ;{ }^{1} \mathrm{H} \mathrm{NMR}\left(300 \mathrm{MHz}, \mathrm{CDCl}_{3}\right) \delta 7.84\left(2 \mathrm{H}, \mathrm{dd},{ }^{3} J_{\mathrm{H}-\mathrm{H}}=6 \mathrm{~Hz},{ }^{4} J_{\mathrm{H}-\mathrm{H}}=3 \mathrm{~Hz}\right.$, $\mathrm{Ar}), 7.71\left(2 \mathrm{H}, \mathrm{dd},{ }^{3} J_{\mathrm{H}-\mathrm{H}}=6 \mathrm{~Hz},{ }^{4} J_{\mathrm{H}-\mathrm{H}}=3 \mathrm{~Hz}, \mathrm{Ar}\right), 4.18\left(4 \mathrm{H}, \mathrm{q},{ }^{3} J_{\mathrm{H}-\mathrm{H}}=7 \mathrm{~Hz}, \mathrm{C}_{2} \mathrm{CH}_{3}\right)$, $4.07\left(2 \mathrm{H}, \mathrm{d},{ }^{2} J_{\mathrm{H}-\mathrm{P}}=11 \mathrm{~Hz}, \mathrm{NCH}_{2} \mathrm{P}\right), 1.30\left(6 \mathrm{H}, \mathrm{t},{ }^{3} \mathrm{~J}_{\mathrm{H}-\mathrm{H}}=7 \mathrm{~Hz}, \mathrm{CH}_{2} \mathrm{CH}_{3}\right) ;{ }^{13} \mathrm{C} \mathrm{NMR}(300$ $\left.\mathrm{MHz} \mathrm{CDCl}_{3}\right) \delta 167.1(\mathrm{C}=\mathrm{O}), 134.4(\mathrm{Ar}), 132.2(\mathrm{Ar}-\mathrm{CO}), 123.7(\mathrm{Ar}), 63.0\left(\mathrm{~d},{ }^{2} J_{\mathrm{C}-\mathrm{P}}=6 \mathrm{~Hz}\right.$, $\left.\mathrm{OC}_{2}\right), 33.5\left(\mathrm{~d},{ }^{1} J_{\mathrm{C}-\mathrm{P}}=157 \mathrm{~Hz}, \mathrm{NC}_{2} \mathrm{P}\right), 16.5\left(\mathrm{~d},{ }^{3} J_{\mathrm{C}-\mathrm{P}}=6 \mathrm{~Hz}, \mathrm{OCH}_{2} \mathrm{CH}_{3}\right) ; v_{\max } / \mathrm{cm}^{-1}$ (ATR) 2984, 2930, $1774(\mathrm{C}=\mathrm{O}), 1716$ (C=O), 1467, 1401, 1381, 1306, 1243, 1050, 1018, 968, 899, 718; m/z (ESMS, ES+) $242\left(100 \%,[(\mathrm{M}-2 \mathrm{Et})+3 \mathrm{H}]^{+}\right), 270\left(25 \%,[(\mathrm{M}-\mathrm{Et})+2 \mathrm{H}]^{+}\right), 298$ $\left(21 \%,[\mathrm{M}+\mathrm{H}]^{+}\right), 320\left(24 \%,[\mathrm{M}+\mathrm{Na}]^{+}\right)$; Anal. Found $\mathrm{C}=52.5 \%, \mathrm{H}=5.8 \%, \mathrm{~N}=4.6 \%$, $\mathrm{C}_{13} \mathrm{H}_{16} \mathrm{NO}_{5} \mathrm{P}$-requires $\mathrm{C}=52.5 \% \mathrm{H}=5.4 \% \mathrm{~N}=4.7 \%$.

Diethyl aminomethylphosphonate (4) 17, 18_Hydrazine (2.1 mL, $60 \mathrm{mmol})$ was added to a solution of the phthalimide $\mathbf{3}(16.05 \mathrm{~g}, 50 \mathrm{mmol})$ in absolute ethanol $(200 \mathrm{~mL})$. The reaction was stirred at room temperature overnight before being heated at reflux for 3 hours. The reaction mixture was then cooled to room temperature and then placed in the refrigerator for several hours. The precipitate that formed was collected by suction filtration and washed with $\mathrm{CH}_{2} \mathrm{Cl}_{2}$. The solvents were then removed under reduced pressure and the residue purified by column chromatography over silica gel eluting with $\mathrm{MeOH}: \mathrm{Et}_{2} \mathrm{O}(1: 2)$ to afford the title compound as a colourless oil $(6.11 \mathrm{~g}, 73 \%)$. 
$R \mathrm{f}=0.3\left(1: 2, \mathrm{MeOH}: \mathrm{Et}_{2} \mathrm{O}, \mathrm{SiO}_{2}\right) ;{ }^{1} \mathrm{H}$ NMR $\left(300 \mathrm{MHz}, \mathrm{CD}_{3} \mathrm{CN}\right) \delta 4.01\left(2 \mathrm{H}, \mathrm{q},{ }^{3} J_{\mathrm{H}-\mathrm{H}}=7 \mathrm{~Hz}\right.$, $\left.\mathrm{OC}_{2} \mathrm{CH}_{3}\right), 3.98\left(2 \mathrm{H}, \mathrm{q},{ }^{3} J_{\mathrm{H}-\mathrm{H}}=7 \mathrm{~Hz}, \mathrm{OC}_{2} \mathrm{CH}^{3}\right), 2.87\left(2 \mathrm{H}, \mathrm{d},{ }^{2} J_{\mathrm{H}-\mathrm{P}}=11 \mathrm{~Hz}, \mathrm{NC}_{2}{ }_{2} \mathrm{P}\right), 2.28$ $\left(2 \mathrm{H}, \mathrm{s} b r, \mathrm{NH}_{2}\right), 1.21\left(6 \mathrm{H}, \mathrm{t},{ }^{3} J_{\mathrm{H}-\mathrm{H}}=7 \mathrm{~Hz}, \mathrm{CH}_{2} \mathrm{CH}_{3}\right) ;{ }^{13} \mathrm{C} \mathrm{NMR}\left(300 \mathrm{MHz}, \mathrm{CD}_{3} \mathrm{CN}\right) \delta 62.1$ $\left(\mathrm{d},{ }^{2} J_{\mathrm{C}-\mathrm{P}}=7 \mathrm{~Hz}, \mathrm{OC}_{2}\right), 37.2\left(\mathrm{~d},{ }^{1} J_{\mathrm{C}-\mathrm{P}}=151 \mathrm{~Hz}, \mathrm{NC}_{2} \mathrm{P}\right), 16.2\left(\mathrm{~d},{ }^{3} J_{\mathrm{C}-\mathrm{P}}=6 \mathrm{~Hz}\right.$, $\left.\mathrm{OCH}_{2} \mathrm{CH}_{3}\right) ; v_{\max } / \mathrm{cm}^{-1}$ (ATR) $3383(\mathrm{NH}), 3297(\mathrm{NH}), 2980,2930,2907,1662(\mathrm{NH}), 1392$, $1228,1163,1050,1021,960 ; \mathrm{m} / \mathrm{z}(\mathrm{ESMS}, \mathrm{ES}+) 139\left(100 \%,[(\mathrm{M}-\mathrm{Et})+2 \mathrm{H}]^{+}\right), 168(66 \%,[\mathrm{M}$ $\left.+\mathrm{H}]^{+}\right)$

Diethyl bromoacetamidomethylphosphonate (5)—The amine 4 (7.0 g, $42.0 \mathrm{mmol}$ ) was added dropwise to a mixture of bromoacetyl bromide $(3.7 \mathrm{~mL}, 42.0 \mathrm{mmol})$ and potassium carbonate $(7.0 \mathrm{~g}, 51.0 \mathrm{mmol})$ in benzene $(50 \mathrm{~mL})$, cooled to $0{ }^{\circ} \mathrm{C}$ in an ice bath, over 30 minutes. The reaction was allowed to warm to room temperature and then stirred for $18 \mathrm{~h}$. The reaction mixture was filtered and the solvents removed under reduced pressure. The residue was purified by column chromatography over silica gel eluting with $10 \% \mathrm{MeOH}$ in $\mathrm{Et}_{2} \mathrm{O}$. The title compound was obtained as a colourless solid $(9.6 \mathrm{~g}, 79 \%)$.

$R_{\mathrm{f}}=0.5\left(10 \% \mathrm{MeOH}\right.$ in $\left.\mathrm{Et}_{2} \mathrm{O}, \mathrm{SiO}_{2}\right) ; \mathrm{mp}=85-86.5{ }^{\circ} \mathrm{C} ;{ }^{1} \mathrm{H} \mathrm{NMR}\left(270 \mathrm{MHz}, \mathrm{CDCl}_{3}\right) \delta 7.46$ $(1 \mathrm{H}, \mathrm{s}$ br, $\mathrm{NH}), 4.13\left(2 \mathrm{H}, \mathrm{q},{ }^{3} J_{\mathrm{H}-\mathrm{H}}=7 \mathrm{~Hz}, \mathrm{OCH}_{2} \mathrm{CH}_{3}\right), 4.10\left(2 \mathrm{H}, \mathrm{q},{ }^{3} J_{\mathrm{H}-\mathrm{H}}=7 \mathrm{~Hz}\right.$, $\left.\mathrm{OCH}_{2} \mathrm{CH}_{3}\right), 3.87\left(2 \mathrm{H}, \mathrm{s}, \mathrm{BrCH}_{2} \mathrm{CO}\right), 3.70\left(2 \mathrm{H}, \mathrm{dd},{ }^{3} J_{\mathrm{H}-\mathrm{H}}=6 \mathrm{~Hz},{ }^{2} J_{\mathrm{H}-\mathrm{P}}=12 \mathrm{~Hz}, \mathrm{NC}_{2} \mathrm{P}\right), 1.31$ $\left(6 \mathrm{H}, \mathrm{t},{ }^{3} J_{\mathrm{H}-\mathrm{H}}=7 \mathrm{~Hz}, \mathrm{CH}_{2} \mathrm{C}_{3}\right) ;{ }^{13} \mathrm{C}$ NMR $\left(270 \mathrm{MHz}, \mathrm{CDCl}_{3}\right) \delta 166.1\left(\mathrm{~d},{ }^{3} J_{\mathrm{C}-\mathrm{P}}=6 \mathrm{~Hz}, \mathrm{C}=\mathrm{O}\right)$, $62.9\left(\mathrm{~d}^{2} J_{\mathrm{C}-\mathrm{P}}=6 \mathrm{~Hz}, \mathrm{OC} \underline{\mathrm{H}}_{2}\right), 35.4\left(\mathrm{~d},{ }^{1} J_{\mathrm{C}-\mathrm{P}}=157 \mathrm{~Hz}, \mathrm{NC}_{2} \mathrm{P}\right) 28.5\left(\mathrm{Br}_{\mathrm{CH}} \mathrm{CO}\right), 16.4$

$\left(\mathrm{d},{ }^{3} \mathrm{~J}_{\mathrm{C}-\mathrm{P}}=6 \mathrm{~Hz}, \mathrm{OCH}_{2} \mathrm{CH}_{3}\right) ; v_{\max } / \mathrm{cm}^{-1}$ (ATR) $3254(\mathrm{NH}), 3058(\mathrm{NH}), 2983,1669(\mathrm{C}=\mathrm{O})$, $1557,1394,1207,1021,979,830 ; \mathrm{m} / \mathrm{z}$ (ESMS, ES-) $288\left(100 \%\right.$, [M-H] $\left.{ }^{-}\right)$, the appropriate isotope pattern was observed; Anal. Found $\mathrm{C}=29.6 \%, \mathrm{H}=5.5 \%, \mathrm{~N}=4.8 \%$, $\mathrm{C}_{7} \mathrm{H}_{15} \mathrm{BrNO}_{4} \mathrm{P}$.requires $\mathrm{C}=29.2 \% \mathrm{H}=5.3 \% \mathrm{~N}=4.9 \%$.

\section{1,4,7,10-Tetraazacyclododecane-1,4,7,10- tetraacetamidomethylene-(diethyl)} phosphonate (6)-Cyclen $(0.43 \mathrm{~g}, 2.5 \mathrm{mmol})$ was dissolved in acetonitrile $(10 \mathrm{~mL})$.

Potassium carbonate $(1.5 \mathrm{~g}, 11.0 \mathrm{mmol})$ and the bromoacetamide $5(2.88 \mathrm{~g}, 10.0 \mathrm{mmol})$ were added and the reaction mixture stirred for $6 \mathrm{~h}$ at $60{ }^{\circ} \mathrm{C}$. The reaction mixture was filtered and the solvents removed under reduced pressure. The residue was taken up into chloroform and heated under reflux for 30 minutes. A precipitate formed that was isolated by filtration. The solids were dried under vacuum to afford the title compound as pale yellow solid (1.52 g, 61 $\%)$.

$\mathrm{mp}=150-150.5^{\circ} \mathrm{C} ;{ }^{1} \mathrm{H}$ NMR $\left(270 \mathrm{MHz}, \mathrm{CDCl}_{3}\right) \delta 7.67(4 \mathrm{H}, \mathrm{s} \mathrm{br}, \mathrm{CON} \underline{\mathrm{H}}), 3.87(8 \mathrm{H}$, q, $\left.{ }^{3} J_{\mathrm{H}-\mathrm{H}}=7 \mathrm{~Hz}, \mathrm{OC} \underline{\mathrm{H}}_{2} \mathrm{CH}_{3}\right), 3.84\left(8 \mathrm{H}, \mathrm{q},{ }^{3} \mathrm{~J}_{\mathrm{H}-\mathrm{H}}=7 \mathrm{~Hz}, \mathrm{OC}_{2} \mathrm{CH}_{3}\right), 3.46\left(8 \mathrm{H}, \mathrm{dd},{ }^{3} J_{\mathrm{H}-\mathrm{H}}=5\right.$ $\left.\mathrm{Hz},{ }^{2} J_{\mathrm{H}-\mathrm{P}}=11 \mathrm{~Hz}, \mathrm{NC}_{2} \mathrm{P}\right), 2.92\left(8 \mathrm{H}, \mathrm{s}, \mathrm{NC}_{2} \mathrm{CO}\right), 2.49\left(16 \mathrm{H}, \mathrm{s}, \operatorname{ring} \mathrm{CH}_{2}\right), 1.05(24 \mathrm{H}$, $\left.\mathrm{t},{ }^{3} J_{\mathrm{H}-\mathrm{H}}=7 \mathrm{~Hz}, \mathrm{CH}_{2} \mathrm{C}_{3}\right) ;{ }^{13} \mathrm{C} \mathrm{NMR}\left(270 \mathrm{MHz}, \mathrm{CDCl}_{3}\right) \delta 170.9(\mathrm{C}=\mathrm{O}), 62.3\left(\mathrm{OC}_{\mathrm{H}}\right), 58.9$ $\left(\mathrm{NCH}_{2} \mathrm{CO}\right), 53.8\left(\right.$ ring $\left.\mathrm{CH}_{2}\right), 34.2\left(\mathrm{~d},{ }^{1} J_{\mathrm{C}-\mathrm{P}}=157 \mathrm{~Hz}, \mathrm{NC}_{2} \mathrm{P}\right), 16.3\left(\mathrm{OCH}_{2} \mathrm{C}_{3}\right) ;{ }^{31} \mathrm{P}$ NMR $\left(300 \mathrm{MHz}, \mathrm{D}_{2} \mathrm{O}\right) \delta 25.65 ; v_{\max } / \mathrm{cm}^{-1}$ (ATR) $3270(\mathrm{NH}), 2982,2826,1670(\mathrm{C}=\mathrm{O}), 1540,1226$. 1050, 1023, 975; m/z (ESMS, ES+) $1002\left(63 \%,[\mathrm{M}+\mathrm{H}]^{+}\right), 1024\left(100 \%,[\mathrm{M}+\mathrm{Na}]^{+}\right) ;$Anal. Found $\mathrm{C}=41.6 \%, \mathrm{H}=7.1 \%, \mathrm{~N}=10.7 \%, \mathrm{C}_{36} \mathrm{H}_{76} \mathrm{~N}_{8} \mathrm{O}_{16} \mathrm{P}_{4} \cdot 0.5 \mathrm{HBr}$ requires $\mathrm{C}=41.5 \% \mathrm{H}=$ $7.4 \% \mathrm{~N}=10.8 \%$.

\section{1,4,7,10-Tetraazacyclododecane-1,4,7,10- tetraacetamidomethylene}

phosphonic acid dihydrobromide (1)-The octaethyl ester 6 ( $0.8 \mathrm{~g}, 0.8 \mathrm{mmol})$ was dissolved in a $30 \%$ solution of $\mathrm{HBr}$ in acetic acid $(8 \mathrm{~mL})$. The resulting solution was stirred at $\mathrm{RT}$ for $18 \mathrm{~h}$. The solvents were removed under reduced pressure and the residue taken up in $\mathrm{EtOH}(5 \mathrm{~mL})$ the solvents were again removed under reduced pressure. The solid residue was then taken up into $\mathrm{MeOH}(5 \mathrm{~mL})$ and the title compound precipitated by drop-wise addition of $\mathrm{Et}_{2} \mathrm{O}$. The resulting precipitate was isolated, dissolved in water and freeze dried to afford a colourless solid $(0.53 \mathrm{~g}, 86 \%)$. 
$\mathrm{mp}=247{ }^{\circ} \mathrm{C}$, decomposes; ${ }^{1} \mathrm{H}$ NMR $\left(300 \mathrm{MHz}, \mathrm{D}_{2} \mathrm{O}\right) \delta 3.67\left(8 \mathrm{H}, \mathrm{s}\right.$ br, $\left.\mathrm{NC}_{2} \mathrm{CO}\right), 3.47(8 \mathrm{H}$, $\left.\mathrm{d},{ }^{2} J_{\mathrm{H}-\mathrm{P}}=12 \mathrm{~Hz}, \mathrm{NC}_{2} \mathrm{P}\right), 3.17\left(16 \mathrm{H}\right.$, s br, ring $\left.\mathrm{C}_{2}\right) ;{ }^{13} \mathrm{C} \mathrm{NMR}\left(270 \mathrm{MHz}, \mathrm{D}_{2} \mathrm{O}\right) \delta 170.7$ (br, $\mathrm{C}=\mathrm{O}), 55.0\left(\mathrm{NCH}_{2} \mathrm{CO}\right), 50.0$ (br, ring $\left.\mathrm{CH}_{2}\right), 36.7\left(\mathrm{~d},{ }^{1} J_{\mathrm{C}-\mathrm{P}}=150 \mathrm{~Hz}, \mathrm{NC}_{2} \mathrm{P}\right) ; v_{\max } /$ $\mathrm{cm}^{-1}$ (ATR) $3235(\mathrm{NH}), 3070(\mathrm{NH}), 2966,2860,1672(\mathrm{C}=\mathrm{O}), 1556,1555,1392,1300,1186$, $1151,1083,990,918 ; \mathrm{m} / \mathrm{z}$ (ESMS, ESI+) $478\left(100 \%,\left[\mathrm{Na}_{8} \mathrm{~L}+2 \mathrm{H}\right]^{2+}\right)$; Anal. Found $\mathrm{C}=23.1$ $\%, \mathrm{H}=5.7 \%, \mathrm{~N}=10.8 \% \mathrm{C}_{20} \mathrm{H}_{44} \mathrm{~N}_{8} \mathrm{O}_{16} \mathrm{P}_{4} \cdot 2.2 \mathrm{HBr} \cdot 4.6 \mathrm{H}_{2} \mathrm{O}$ requires $\mathrm{C}=23.2 \%, \mathrm{H}=5.4 \%$, $\mathrm{N}=10.8 \%$

\section{Potentiometric Titrations}

Materials-Stock solutions of $\mathrm{CaCl}_{2}, \mathrm{ZnCl}_{2}, \mathrm{CuCl}_{2}$, and $\mathrm{GdCl}_{3}$ were prepared from analytical-grade salts (Aldrich and Sigma, 99.9\%), all other solutions were prepared from the highest analytical grade materials commercially available, using HPLC grade water (Omni Solv). The concentrations of the stock solutions were determined by complexometric titration using a standardized $\mathrm{Na}_{2} \mathrm{H}_{2}$ EDTA solution in the presence of calconcarboxylic acid $\left(\mathrm{CaCl}_{2}\right)$, eriochrome black- $\mathrm{T}\left(\mathrm{ZnCl}_{2}\right)$, murexide $\left(\mathrm{CuCl}_{2}\right)$, and xylenol orange $\left(\mathrm{LnCl}_{3}\right)$ as an indicator. A stock solution of the ligand was prepared, and the ligand concentration was determined by $\mathrm{pH}$ potentiometry on the basis of the titration curves obtained in the absence and presence of excess $\mathrm{CaCl}_{2}$. Aliquots from the stock solution of $\mathbf{1}$ were diluted into $1.0 \mathrm{M}$ solutions of $\mathrm{Me}_{4} \mathrm{NCl}$ and $\mathrm{KCl}$ and the $\mathrm{pH}$ adjusted to $\sim 1.7$ with $\mathrm{HCl}$. These solutions were titrated with $0.2173 \mathrm{M} \mathrm{Me}_{4} \mathrm{NOH}\left(\mathrm{Me}_{4} \mathrm{NCl}\right)$ or $0.1679 \mathrm{M} \mathrm{KOH}(\mathrm{KCl})$ to a final $\mathrm{pH}$ of $\sim 12.5$.

Measurements made using $\mathrm{KCl}$ for ionic strength-The potentiometric measurements were carried out with an automatic titration system. The $\mathrm{pH}$ was measured in each titration with a Ross semi-micro combination electrode (Orion) combined with a Thermo Orion IonAnalyzer EA 940. The samples were titrated using a model 665 Metrohm Dosimat autoburet. All potentiometric titrations were conducted under an argon atmosphere and the cell was maintained at a constant $25 \pm 0.1{ }^{\circ} \mathrm{C}$ by using a circulating water bath. The titrated solutions $(10 \mathrm{~mL})$ were stirred. The electrode was calibrated by KH-phtalate $(\mathrm{pH} \mathrm{4.005)}$ and Natetraborate ( $\mathrm{pH} 9.180$ ) (Alfa Aesar). Titrations of each sample were performed over the $\mathrm{pH}$ range 1.7-12.5, the concentrations of the 1 and the Gd1 were $0.002 \mathrm{M}$ in the samples and $1 \mathrm{M}$ $\mathrm{KCl}$ was used to maintain the ionic strength. Hydrogen ion concentrations were calculated from the measured $\mathrm{pH}$ values using the method proposed by Irving et. al. ${ }^{45}$ The value of $\mathrm{pK}_{\mathrm{w}}$ used at $\mathrm{I}=1.0(\mathrm{KCl})$ was 13.81 which was determined experimentally under similar conditions to that used for the titrations.

Measurements made using $\mathrm{Me}_{4} \mathrm{NCl}$ for ionic strength were similar to that described previously except that the titrations were performed with a Radiometer PHM93 pH-meter, an ABU 80 autoburet, and Metrohm 6.0234.100 combined electrode and the volume of the titrated solutions were $5 \mathrm{~mL}$. The value of the $\mathrm{pK}_{\mathrm{w}}$ at $\mathrm{I}=1.0\left(\mathrm{Me}_{4} \mathrm{NCl}\right)$ was determined experimentally and found to be 14.06. Protonation constants were calculated from the potentiometric titrations curves using the program PSEQUAD. 46

\section{Supplementary Material}

Refer to Web version on PubMed Central for supplementary material.

\section{Acknowledgements}

The authors thank the National Institutes of Health (EB-04285, MW) and (CA-115531 and RR-02584, ADS), the EMIL Project funded by the EC FP6 Framework Program (FKK, RK and EB) and the Robert A. Welch Foundation (AT-584) for financial support of this work. 


\section{References}

1. Sennoune Souad R, Luo D, Martinez-Zaguilan R. Cell Biochem. Biophys 2004;40:185. [PubMed: 15054222]

2. Tannock IF, Rotin D. Cancer Res 1989;49:4373. [PubMed: 2545340]

3. Vaupel P, Kallinowski F, Okunieff P. Cancer Res 1989;49:6449. [PubMed: 2684393]

4. Wike-Hooley JL, Haveman J, Reinhold JS. Radioter. Oncol 1984;2:343.

5. Caravan P, Ellison JJ, McMurry TJ, Lauffer RB. Chem. Rev 1999;99:2293. [PubMed: 11749483]

6. Lauffer RB. Chem. Rev 1987;87:901.

7. Messeri D, Lowe MP, Parker D, Botta M. Chem. Commun 2001:2742.

8. Woods M, Zhang S, Kovacs Z, Sherry AD. Adv. Supramol. Chem 2003;9:1.

9. Aime S, Barge A, Botta M, Howard JAK, Kataky R, Lowe MP, Moloney JM, Parker D, de Sousa AS. Chem. Commun 1999:1047.

10. Hovland R, Glogard C, Aasen AJ, Klaveness J. J. Chem. Soc., Perkin Trans. 2 2001:929.

11. Lowe MP, Parker D. Chem. Commun 2000:707.

12. Woods M, Zhang S, Von Howard E, Sherry AD. Chem. Eur. J 2003;9:4634.

13. Zhang S, Wu K, Sherry AD. Angew. Chem., Int. Ed 1999;38:3192.

14. Raghunand N, Howison C, Sherry AD, Zhang S, Gillies RJ. Magn. Reson. Med 2003;49:249. [PubMed: 12541244]

15. Garcia-Martin ML, Martinez GV, Raghunand N, Sherry AD, Zhang S, Gillies RJ. Magn. Reson. Med 2006;55:309. [PubMed: 16402385]

16. Raghunand N, Zhang S, Sherry AD, Gillies Robert J. Acad. Radiol 2002;9:S481. [PubMed: 12188315]

17. Yamauchi K, Imoto M, Kinoshit M. Bull. Chem. Soc. Jpn 1972;45:2531.

18. Yamauchi K, Mitsuda Y, Kinoshita M. Bull. Chem. Soc. Jpn 1975;48:3285.

19. Woods M, Sherry AD. Inorg. Chem 2003;42:4401. [PubMed: 12844313]

20. Aime S, Barge A, Bruce JI, Botta M, Howard JAK, Moloney JM, Parker D, de Sousa AS, Woods M. J. Am. Chem. Soc 1999;121:5762.

21. Komiyama M, Takeda N, Shigekawa H. Chem. Commun 1999:1443.

22. Di Bari L, Pescitelli G, Sherry AD, Woods M. Inorg. Chem 2005;44:8391. [PubMed: 16270977]

23. Dickins RS, Parker D, Bruce JI, Tozer DJ. Dalton Trans 2003:1264.

24. Toth E, Brucher E, Lazar I, Toth I. Inorg. Chem 1994;33:4070.

25. Baranyai Z, Bruecher E, Ivanyi T, Kiraly R, Lazar I, Zekany L. Helv. Chim. Acta 2005;88:604.

26. Stenson PA, Thompson AL, Parker D. Dalton Trans 2006:3291. [PubMed: 16820839]

27. Bloembergen N. J. Chem. Phys 1957;27:572.

28. Bloembergen N, Morgan LO. J. Chem. Phys 1961;34:842.

29. Bloembergen N, Purcell EM, Pound RV. Phys. Rev 1948;73:679.

30. Solomon I. Phys. Rev 1955;99:559.

31. Solomon I, Bloembergen N. J. Chem. Phys 1956;25:261.

32. Aime S, Fasano M, Terreno E. Chem. Soc. Rev 1998;27:19.

33. Caravan P, Cloutier NJ, Greenfield MT, McDermid SA, Dunham SU, Bulte JWM, Amedio JC Jr, Looby RJ, Supkowski RM, Horrocks WD Jr, McMurry TJ, Lauffer RB. J. Am. Chem. Soc 2002;124:3152. [PubMed: 11902904]

34. Botta M. Eur. J. Inorg. Chem 2000:399.

35. Pasha A, Tircsó G, Brücher E, Sherry AD. Unpublished Data. 2006

36. Andre JP, Bruecher E, Kiraly R, Carvalho RA, Maecke H, Geraldes CFGC. Helv. Chim. Acta 2005;88:633.

37. Burai L, Fabian I, Kiraly R, Szilagyi E, Brucher E. J. Chem. Soc., Dalton Trans 1998:243.

38. Kumar K, Jin TZ, Wang XY, Desreux JF, Tweedle MF. Inorg. Chem 1994;33:3823.

39. Popov K, Rónkkömäk H, Lajunen LJ. Pure Appl. Chem 2001;73:1641-1677.

Inorg Chem. Author manuscript; available in PMC 2008 September 12. 
40. May PM, Linder PW, Williams DR. J. Chem. Soc., Dalton Trans 1977:588.

41. Zhang S, Wu K, Biewer MC, Sherry AD. Inorg. Chem 2001;40:4284. [PubMed: 11487334]

42. Avecilla F, Peters JA, Geraldes CFGC. Eur. J. Inorg. Chem 2003:4179.

43. Aime S, Batsanov AS, Botta M, Dickins RS, Faulkner S, Foster CE, Harrison A, Howard JAK, Moloney JM, Norman TJ, Parker D, Royle L, Williams JAG. J. Chem. Soc., Dalton Trans 1997:3623.

44. Aime S, Batsanov AS, Botta M, Howard JAK, Parker D, Senanayake K, Williams G. Inorg. Chem 1994;33:4696.

45. Irving HM, Miles MG, Pettit LD. Anal. Chim. Acta 1967;38:475.

46. Zékány, L.; Nagypál, I. Computational Methods for Determination of Formation Constants. Legget, DJ., editor. New York: 1985. 

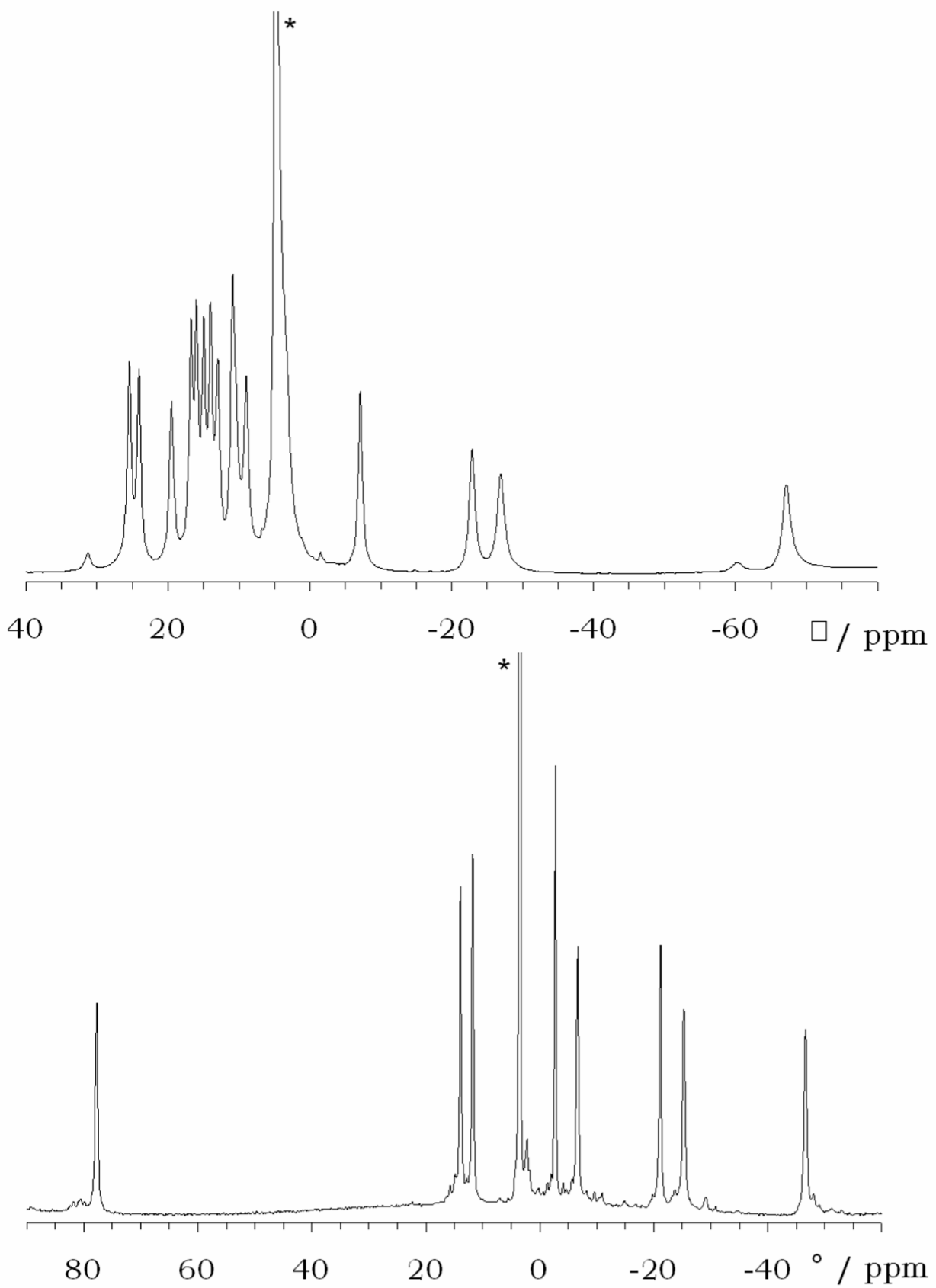

Figure 1.

The ${ }^{1} \mathrm{H}$ NMR spectra of Yb1 complexes synthesized and recorded at a) $\mathrm{pH} \mathrm{1,} \mathrm{b)} \mathrm{pH} \mathrm{9.} \mathrm{The}$ spectra were recorded in $\mathrm{D}_{2} \mathrm{O}$ at $296 \mathrm{~K}$ and $270 \mathrm{MHz}$ (the peaks arising from HOD are labelled with asterisks). 

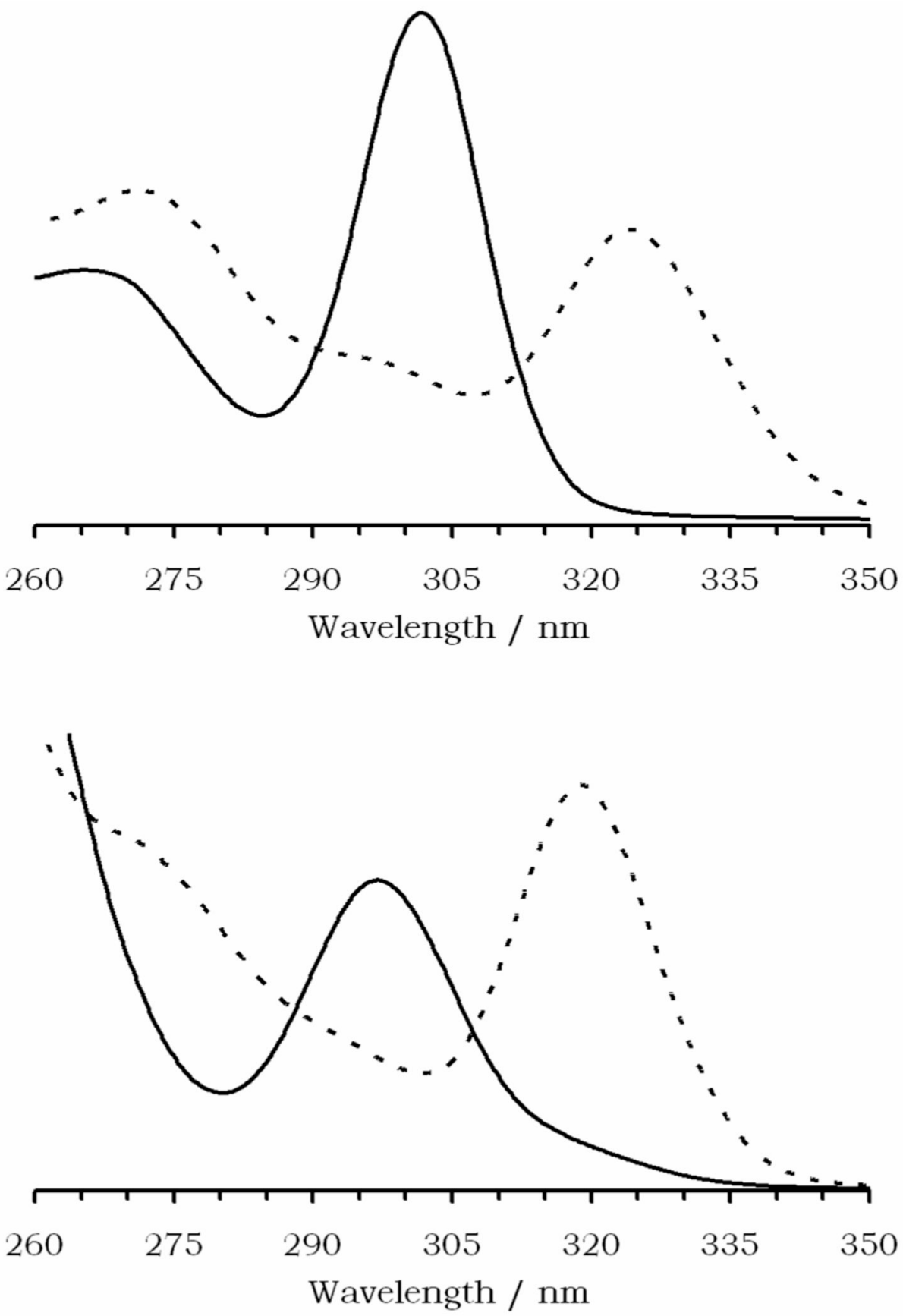

Figure 2.

UV-visible absorption spectra of Ce1 (top) prepared at pH 1 (solid line) and pH 9 (dashed line). The absorption bands are similar to those observed for the Type I (solid line) and Type II (dashed line) complexes of CeDOTA (bottom). 


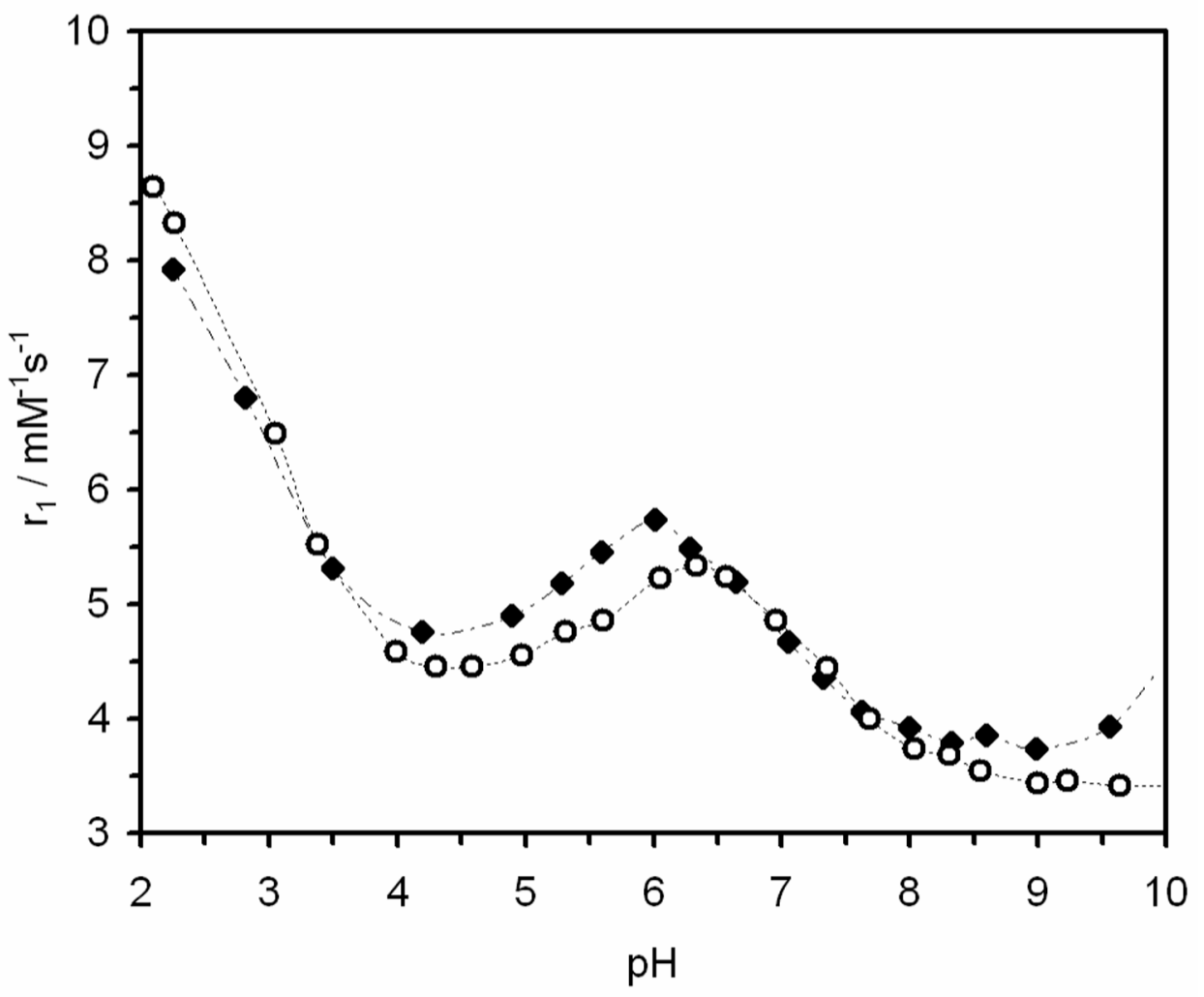

Figure 3.

The effect of solution $\mathrm{pH}$ on the relaxivity of $\mathrm{Gd} \mathbf{1}$ (open circles), recorded at $25{ }^{\circ} \mathrm{C}$ and 20 $\mathrm{MHz}([\mathrm{Gd} \mathbf{1}]=1.0 \mathrm{mM})$. The effect of solution $\mathrm{pH}$ on the relaxivity of $\mathrm{Gd} \mathbf{1}$ in the presence of $135 \mathrm{mM} \mathrm{NaCl}, 5 \mathrm{mM} \mathrm{KCl}$ and $2.5 \mathrm{mM} \mathrm{CaCl} 2([\mathrm{Gd} \mathbf{1}]=1 \mathrm{mM})$ is also shown (filled diamonds). Profiles recorded at $15^{\circ} \mathrm{C}$ and $35^{\circ} \mathrm{C}$ are provided as supplementary material. 


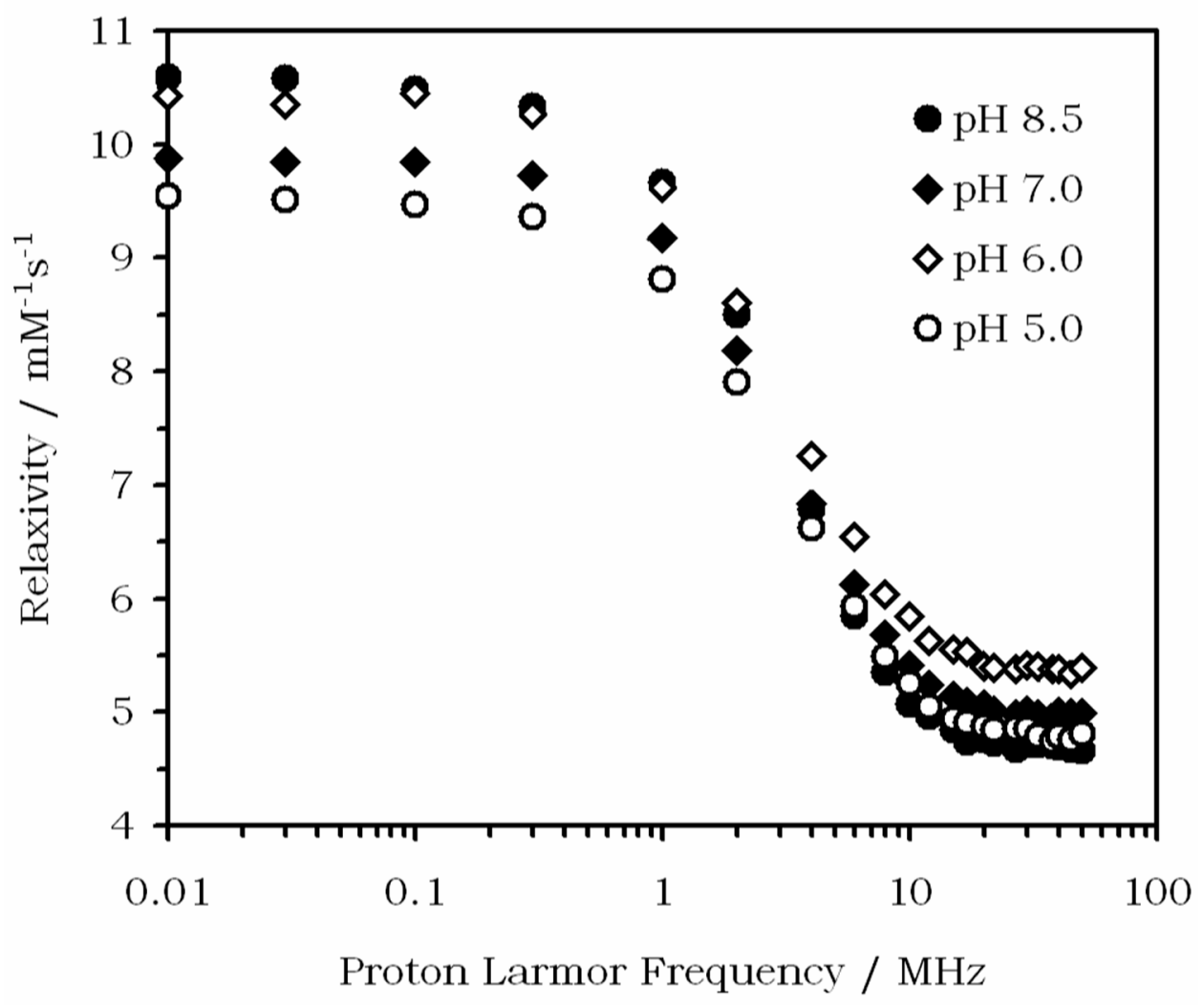

Figure 4.

Nuclear magnetic relaxation dispersion (NMRD) profiles for $\mathrm{Gd} \mathbf{1}$ at $25^{\circ} \mathrm{C}$ and $\mathrm{pH} 5$ (open circles), pH 6 (open diamonds), pH 7 (closed diamonds) and pH 8.5 (closed circles). The pH for these experiments was maintained by using HEPES buffers. 


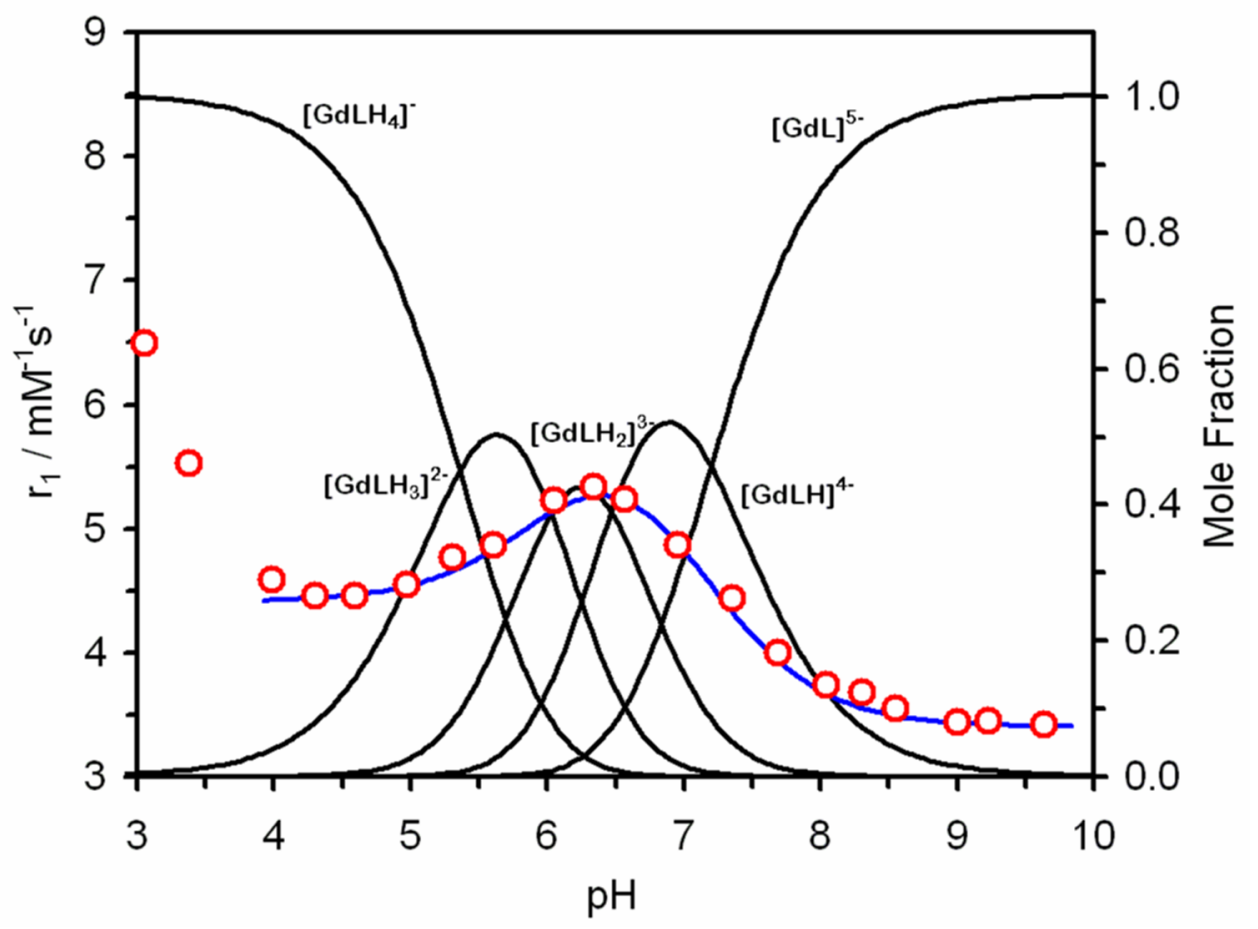

Figure 5.

The longitudinal relaxivity $\mathrm{pH}$ profile of $\mathrm{Gd} \mathbf{1}\left(25^{\circ} \mathrm{C}, 20 \mathrm{MHz}\right)$ (red circles) laid-over the speciation diagram of Gd1. The blue line is the overall relaxivity of the system calculated from the relaxivity of each species (Table 5) as determined by the regression analysis. 


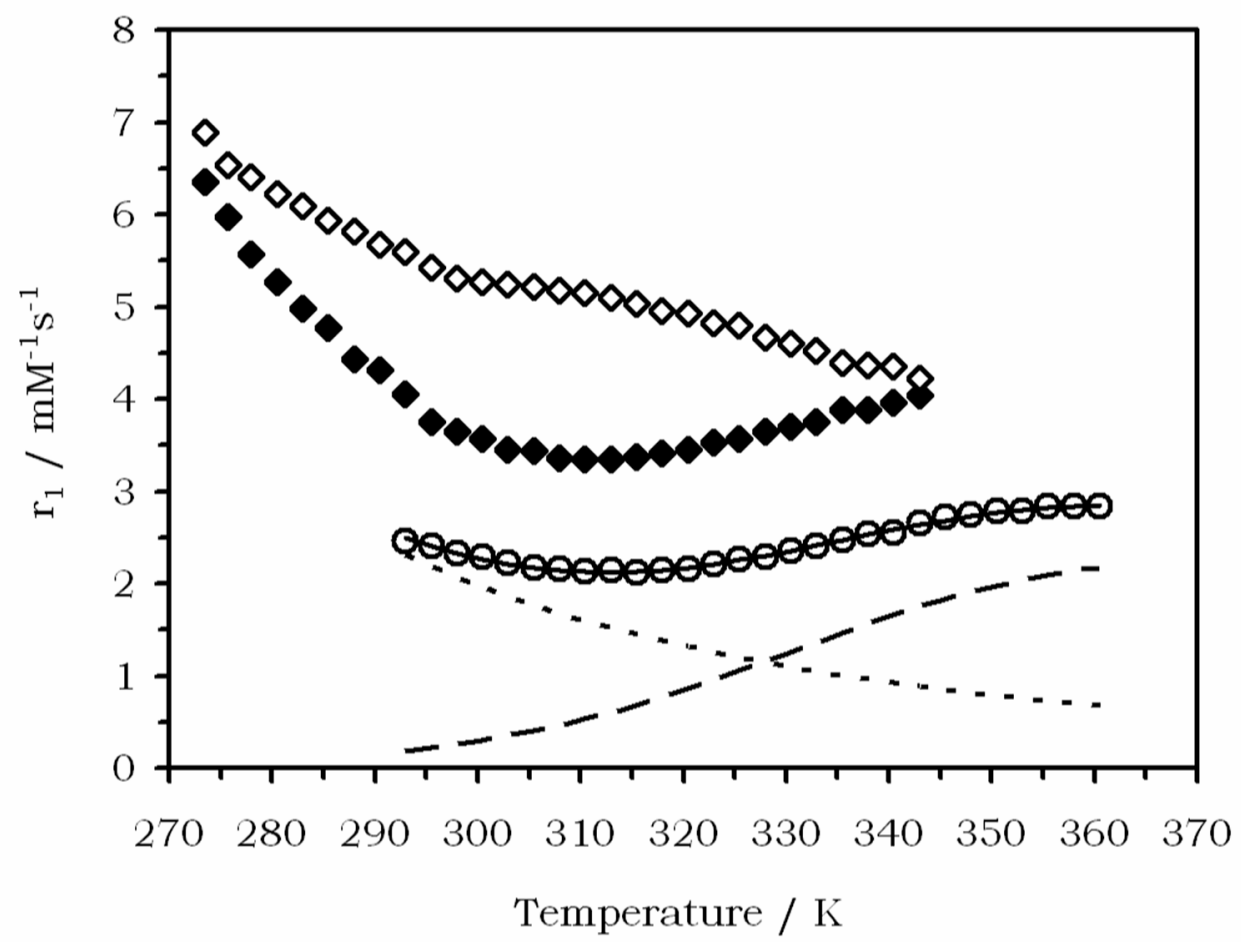

Figure 6.

The temperature dependence of the relaxivity of $\mathrm{Gd} \mathbf{1}$ at $\mathrm{pH} 6.2$ (open diamonds) and $\mathrm{pH} 8.3$ (closed diamonds). The temperature dependence of the relaxivity of $\mathrm{Gd} 2$ is shown for comparison (open circles), the calculated relaxivity (solid line), the outer-sphere contribution (dotted line) and the inner-sphere contribution (dashed line) are also shown. 

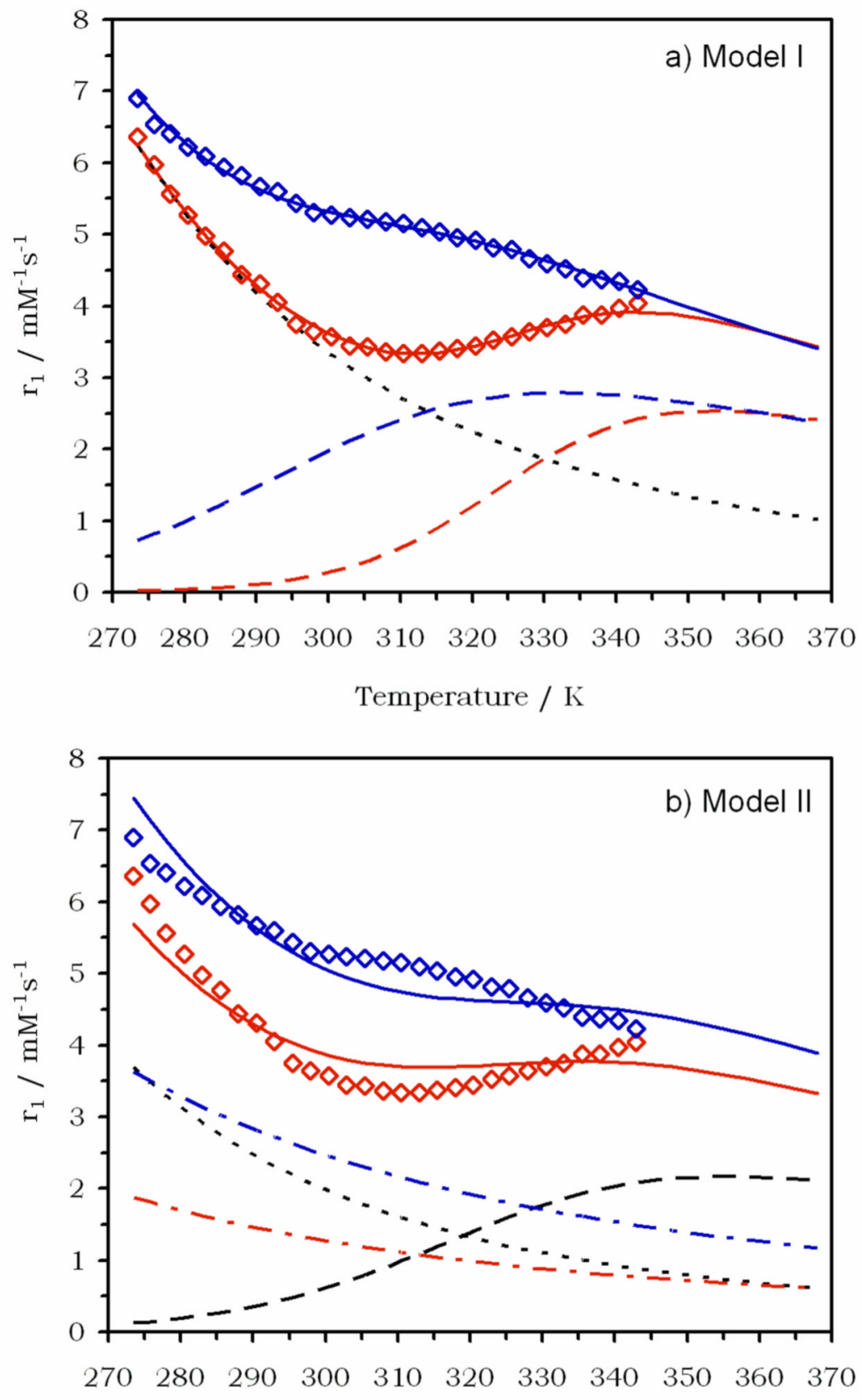

Temperature / K

Figure 7.

Fitting the temperature dependence of the relaxivity of $\mathrm{Gd} 1$ at $\mathrm{pH} 6.2$ (blue) and $\mathrm{pH} 8.3$ (red) to: a) a model that fixes the outer and second sphere contributions (dotted black line) and fits the data to changes in the inner sphere relaxivity (dashed lines). The fits are shown as solid lines. b) a model that assumes no change in inner-sphere relaxivity (dashed black line) and accounts for difference in relaxivity through changes in the second sphere contribution (dotdash lines). The outer-sphere contribution (dotted black line) and fits (solid lines are also shown. 


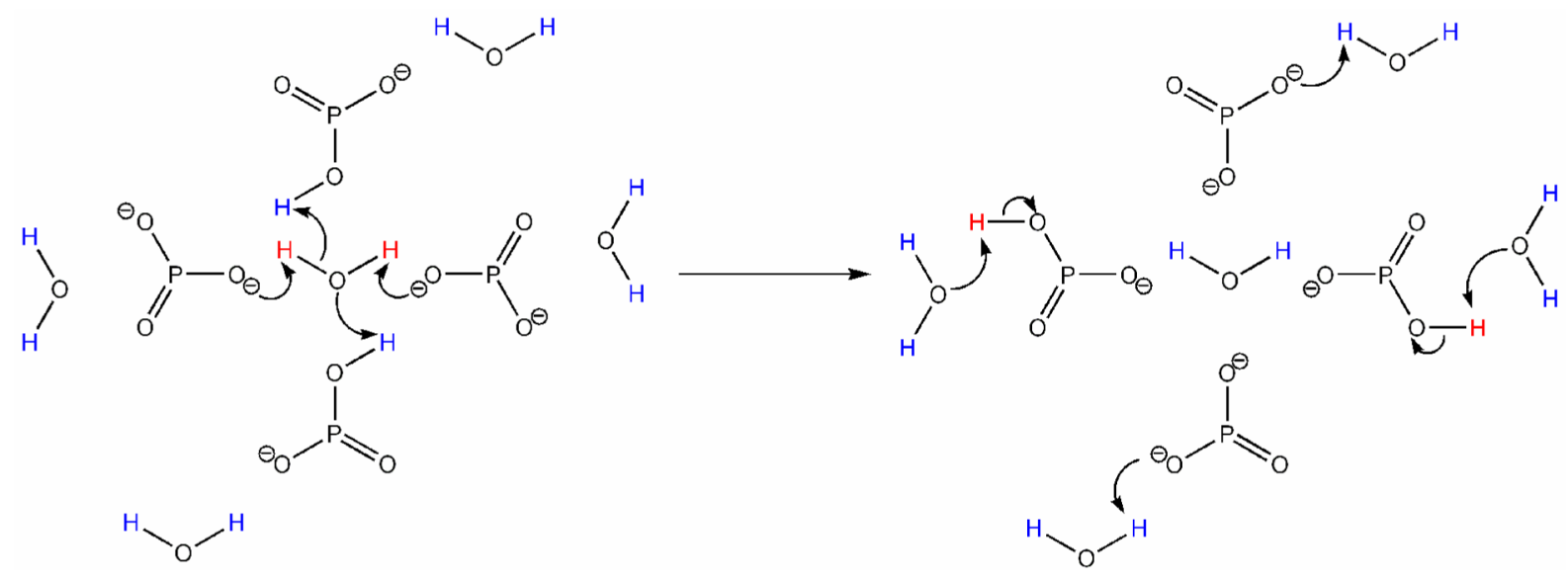

Figure 8.

A schematic representation, viewed down the $\mathrm{Gd}-\mathrm{OH}_{2}$ axis, of how the phosphonates in $\mathrm{GdLH}_{2}{ }^{3-}$ transfer protons between the coordinated water molecule and the bulk solvent. The relaxed protons of the coordinated water molecule (shown in red) are removed from the water molecule by the deprotonated phosphonates which act as bases. They are then replaced by unrelaxed protons from the bulk water (shown in blue) which are supplied by the monoprotonated phosphonates which are acting as acids. 
<smiles>CCOCN1C(=O)c2ccccc2C1=O</smiles>

3<smiles>C#CCOCC#CCBr</smiles>

4

5<smiles>[R]NC(=O)CN1CCN(CC(N)=O)CCN(CC(=O)N[R])CCN(CC(N)=O)CC1</smiles>

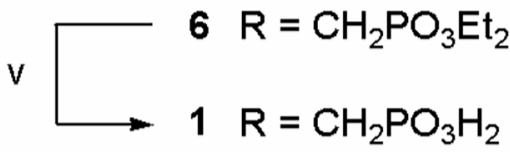

Scheme 1.

Synthesis of 1. Reagents and conditions: i.) $\mathrm{P}(\mathrm{OEt})_{3} / \Delta$; ii.) $\mathrm{N}_{2} \mathrm{H}_{4} / \mathrm{EtOH}$; iii.) $\mathrm{BrCH}_{2} \mathrm{COBr} /$ $\mathrm{K}_{2} \mathrm{CO}_{3}$ / benzene; iv.) cyclen / $\mathrm{K}_{2} \mathrm{CO}_{3} / \mathrm{MeCN} / 60^{\circ} \mathrm{C}$; v.) $30 \% \mathrm{HBr} / \mathrm{AcOH} / \mathrm{RT}$. 


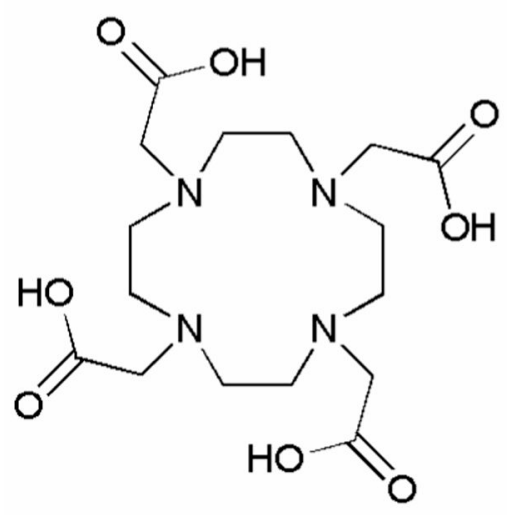

$\mathrm{H}_{4}$ DOTA

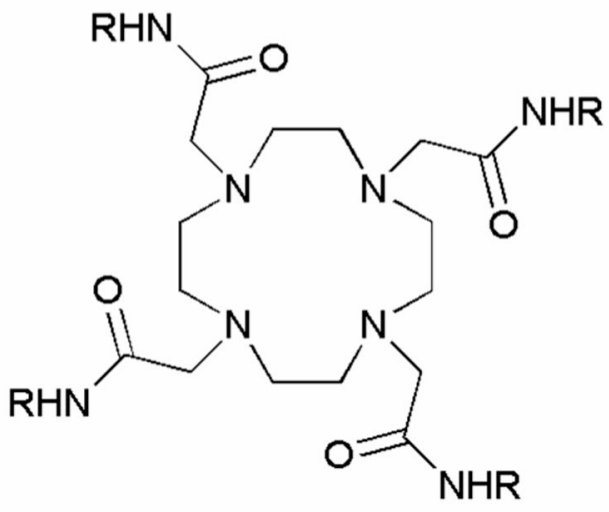

$$
\begin{array}{ll}
\mathrm{R}=\mathrm{H} & \text { DOTAM } \\
\mathrm{R}=\mathrm{CH}_{2} \mathrm{PO}_{3} \mathrm{H}_{2} & \text { DOTA-4AmP 1 } \\
\mathrm{R}=\mathrm{CH}_{2} \mathrm{CO}_{2} \mathrm{Et} & 2
\end{array}
$$

Chart 1.

Inorg Chem. Author manuscript; available in PMC 2008 September 12. 
Table 1

The protonation constants of ligand 1 as determined by potentiometric titration at $25^{\circ} \mathrm{C}$ in either $1.0 \mathrm{M} \mathrm{Me} 4 \mathrm{NCl}$ or $\mathrm{KCl}$. The correlation coefficients of these determinations are examined in the Supplementary Information (S4).

\begin{tabular}{|c|c|c|}
\hline & $1.0 \mathrm{M} \mathrm{Me}{ }_{4} \mathrm{NCl}$ & $1.0 \mathrm{M} \mathrm{KCl}$ \\
\hline $\begin{array}{l}\log K_{1}{ }^{\mathrm{H}} \\
\log K_{2}{ }^{\mathrm{H}} \\
\log K_{3}{ }_{\mathrm{H}} \\
\log K_{4}{ }^{\mathrm{H}} \\
\log K_{5}{ }^{\mathrm{H}} \\
\log K_{6}{ }_{\mathrm{H}} \\
\log K_{7}{ }^{\mathrm{H}} \\
\log K_{8}{ }^{\mathrm{H}}\end{array}$ & $\begin{array}{l}9.97 \pm 0.03 \\
7.84 \pm 0.05 \\
7.44 \pm 0.04 \\
7.01 \pm 0.04 \\
6.50 \pm 0.04 \\
5.91 \pm 0.03 \\
2.46 \pm 0.04 \\
1.92 \pm 0.03\end{array}$ & $\begin{array}{c}8.78 \pm 0.03 \\
7.69 \pm 0.03 \\
7.21 \pm 0.04 \\
6.66 \pm 0.04 \\
6.17 \pm 0.04 \\
5.44 \pm 0.04 \\
2.17 \pm 0.05 \\
1.1 \pm 0.1\end{array}$ \\
\hline
\end{tabular}


Table 2

The thermodynamic stability constants of complexes formed between ligand $\mathbf{1}$ and sodium, potassium and calcium at $25^{\circ} \mathrm{C}$ in $1.0 \mathrm{M} \mathrm{Me}_{4} \mathrm{NCl}$.

\begin{tabular}{cccc}
\hline & $\mathbf{N a}^{+}$ & $\mathbf{K}^{+}$ & $\mathbf{C a}^{\mathbf{2}}$ \\
\hline $\log K_{\mathrm{ML}}$ & $3.72 \pm 0.03$ & $2.34 \pm 0.09$ & $11.16 \pm 0.07$ \\
$\log K_{\mathrm{MLH}}$ & $7.87 \pm 0.06$ & $8.86 \pm 0.06$ & $8.00 \pm 0.07$ \\
$\log K_{\mathrm{MLH}}$ & $7.77 \pm 0.04$ & - & $7.22 \pm 0.07$ \\
$\log K_{\mathrm{MLH}}$ & - & - & $6.70 \pm 0.07$ \\
$\log K_{\mathrm{MLH}}$ & - & - & $5.93 \pm 0.04$ \\
$\log K_{\mathrm{M}_{2} \mathrm{~L}}$ & - & - & $2.76 \pm 0.05$ \\
$\log K_{\mathrm{M}_{2} \mathrm{LH}}$ & - & & $7.60 \pm 0.07$ \\
\hline
\end{tabular}


Table 3

The protonation constants of the Type II complex of $\mathrm{Gd} 1,25^{\circ} \mathrm{C}, 1.0 \mathrm{M} \mathrm{KCl}$. The correlation coefficients of these determinations are examined in the Supplementary Information (S4).

\begin{tabular}{lc}
\hline & $\mathbf{p K}_{\mathbf{a}}$ \\
\hline $\log K_{\mathrm{GdLH}_{1}}$ & $7.20 \pm 0.01$ \\
$\log K_{\mathrm{GdLH}_{2}}$ & $6.47 \pm 0.01$ \\
$\log K_{\mathrm{GdLH}_{3}}$ & $6.03 \pm 0.01$ \\
$\log K_{\mathrm{GdLH}_{4}}$ & $5.36 \pm 0.01$ \\
\hline
\end{tabular}


Table 4

Stability constants $\left(\log K_{\mathrm{GdLM}}\right)$ and protonation constants $\left(\log K_{\mathrm{GdMLH}}\right)$ for the ternary complexes of $\mathrm{Gd} \mathbf{1}\left(25^{\circ} \mathrm{C}, 1.0 \mathrm{M}\right.$ $\mathrm{KCl})$.

\begin{tabular}{|c|c|c|c|}
\hline Equilibrium & $\mathbf{M}=\mathbf{C a}^{2+}$ & $\mathbf{M}=\mathrm{Zn}^{2+}$ & $\mathbf{M}=\mathbf{C u}^{2+}$ \\
\hline $\begin{array}{c}\log K_{\mathrm{GdLM}} \\
\log K_{\mathrm{GdLMH}}\end{array}$ & $\begin{array}{l}1.87 \pm 0.04 \\
6.94 \pm 0.05\end{array}$ & $\begin{array}{l}5.28 \pm 0.05 \\
6.98 \pm 0.02\end{array}$ & $\begin{array}{l}5.39 \pm 0.04 \\
6.18 \pm 0.04\end{array}$ \\
\hline
\end{tabular}


Table 5

The calculated water relaxivities of each protonated Gd1 species (calculated from the data of Figure 5).

\begin{tabular}{cc}
\hline Species & $\mathbf{r}_{\mathbf{1}} / \mathbf{m M}^{-\mathbf{1}} \mathbf{s}^{\mathbf{- 1}}$ \\
\hline $\mathrm{GdL}^{5-}$ & 3.4 \\
$\mathrm{GdLH}^{4-}$ & $5.50 \pm 0.11$ \\
$\mathrm{GdLH}_{2}{ }^{--}$ & $5.57 \pm 0.17$ \\
$\mathrm{GdLH}_{3}{ }^{--}$ & $4.77 \pm 0.18$ \\
$\mathrm{GdLH}_{4}{ }^{-}$ & $4.42 \pm 0.11$ \\
\hline
\end{tabular}

